\title{
Tax Aspects of Canadian Fiscal Federalism
}

\author{
Benjamin Alarie and Richard M. Bird ${ }^{1}$ \\ September 30, 2010
}

\section{Introduction}

In the constitutional moment known to Canadians as Confederation, in 1867 the UK Parliament passed the British North America Act, 1867 (now known as the Constitution Act, 1867), ${ }^{2}$ thereby creating the Dominion of Canada. From the time of Confederation, there have been, broadly speaking, two sets of issues addressed through Canadian federalism-cultural issues and economic issues. ${ }^{3}$ The cultural issues most prominently relate to the means of mutually accommodating Canada's "two solitudes" - the English and French heritages of the country. ${ }^{4}$ The economic issues relate to monetary and fiscal policies, the regulation of internal and external trade, and the governance of economic relationships within Canada. This chapter focuses on just a subset of the economic issues. More specifically, this chapter addresses the tax aspects of Canadian fiscal federalism. ${ }^{5}$

Canada has three levels of government: one national and two subnational. At the national level is Canada's federal government. The federal government has constitutional responsibility to make laws to promote "peace, order and good government." Canada's current population of 33.7 million $^{6}$ resides in its ten provinces and three territories. These provinces and territories constitute the first subnational level of government and range widely in geographic size, population, and economic significance. At one end of the spectrum lie the vast and sparsely populated territories of Nunavut, Yukon and Northwest Territories (a population of 0.1 million on 3.9 million $\mathrm{km}^{2}$ ) and tiny Prince Edward Island (a population of 0.1 million on $5,660 \mathrm{~km}^{2}$ ). At the opposite end of the spectrum are the centrally located, large, and populous provinces of Ontario (a population of 13.1 million on 1.1 million $\mathrm{km}^{2}$, predominantly English speaking) and Québec (a population of 7.8 million on 1.5 million $\mathrm{km}^{2}$, predominantly French speaking). ${ }^{7}$

Local governments are the second subnational level of government. These are also highly heterogeneous, and vary in purpose, size and structure. Unlike the provinces and the federal government, local governments have no explicit constitutional status and are the product of

\footnotetext{
${ }^{1}$ The authors are Associate Professor, Faculty of Law, University of Toronto, and Professor Emeritus of Economics, University of Toronto, respectively. Thanks to Akash Trapani, JD Candidate, 2012, for his excellent research assistance.

${ }^{2} 30$ \& 31 Victoria, c. 3. (U.K.).

${ }^{3}$ See Donald V. Smiley, "The Two Themes of Canadian Federalism" (1965) 31(1) Canadian Journal of Economics and Political Science 80-97.

${ }^{4}$ The term "two solitudes" gained prominence in Canada following the publication of the novel of that name by Hugh McLennan in 1945; see Hugh McLennan, Two Solitudes (Toronto: Macmillan, 1945).

${ }^{5}$ It should be noted that there are many unique issues surrounding the treatment of Canada's aboriginal peoples in respect of taxation that this chapter does not address.

${ }^{6}$ This is estimated as of July 1, 2009. See Statistics Canada, "Population Projections for Canada, Provinces and Territories, Catalogue no. 91-520-X" (Ottawa, 2010) at p. 19.

${ }^{7}$ Ibid.
} 
powers delegated by the provinces and territories. Local governments range from small rural communities and local school boards, to large municipalities, such as the City of Toronto (official population 2.5 million; metropolitan area population, 5.6 million). The City of Toronto's size gives it a greater number of inhabitants than a majority of the provinces and territories. ${ }^{8}$ As one might expect, given these vast disparities, the roles and responsibilities of local governments vary widely and defy definitive general description. ${ }^{9}$ In light of the constitutional non-recognition of local governments, unless stated otherwise, the two subnational levels of government-provinces and territories on the one hand and local governments on the otherwill be discussed as constituting one subnational level.

The Constitution Act, 1867 gives to the federal government essentially unlimited jurisdiction to impose tax, including all direct taxes and indirect taxes. In 2007-2008, the federal government raised cumulatively $\$ 203.6$ billion-about $13.1 \%$ of GDP-through taxation. ${ }^{10}$ In recent decades, by far the most important source of federal tax revenues has been the income tax. In 2007-2008, the federal government raised \$159.4 billion through income taxes, \$29.9 billion through the federal value-added tax (the "Goods and Services Tax" or "GST"), and \$14.3 billion through customs duties and excise taxes of various kinds. ${ }^{11}$

In contrast to the broad taxation powers given to the federal government at Confederation, the tax powers allocated to the provinces are specifically delineated in the Constitution Act, 1867. The principal power is to impose "direct taxation" in the province to raise revenues for provincial purposes; a subsidiary power is to raise revenues through licence fees. The provincial powers can be-and frequently are-delegated by the provinces to local governments. In order of revenues generated, the most important sources of revenue subnationally are income taxes, various sales, excise, and value-added taxes, and property taxes. On a consolidated basis in 2007-2008, Canadian provincial, territorial, and local governments raised $\$ 110.1$ billion through income taxes, ${ }^{12} \$ 62.4$ billion through sales, excise, and value-added taxes, ${ }^{13}$ and $\$ 53.9$ billion through property and related taxes. ${ }^{14}$

\footnotetext{
${ }^{8}$ The population of the City of Toronto in 2006 was 2.5 million; see City of Toronto, "Population and Dwelling Counts" http://www.toronto.ca/invest-in-toronto/pop dwell.htm. As a census metropolitan area, Toronto had a population of about 5.6 million; see Statistics Canada, "Population of census metropolitan areas (2006 census boundaries)" http://www40.statcan.gc.ca/l01/cst01/demo05a-eng.htm. Among the provinces and territories, only Ontario, Québec, Alberta and British Columbia have populations larger than the City of Toronto.

9 "Because local governments vary so greatly in terms of form and function, it is almost impossible to paint a definitive picture of this level of government." See Karin Treff and Deborah Ort, Finances of the Nation, 2009 (Canadian Tax Foundation, 2010) at p. 1:4.

${ }^{10}$ This is about $13.1 \%$ of Canada's GDP over this period. See Source: Statistics Canada, CANSIM, table (for fee) $380-$ 0001 and Catalogue no. 13-001-X; available online at: http://www40.statcan.gc.ca/l01/cst01/econ03-eng.htm.

${ }^{11}$ See Karin Treff and Deborah Ort, Finances of the Nation, 2009 (Canadian Tax Foundation, 2010) at p. 2:2.

${ }^{12}$ Authors' calculations based on figures reported in Karin Treff and Deborah Ort, Finances of the Nation, 2009 (Canadian Tax Foundation, 2010) at pp. 1: 2 and 2:2.

${ }^{13}$ This figure includes general sales taxes, gasoline taxes, alcohol and tobacco taxes, as well as some other miscellaneous sales taxes. See Karin Treff and Deborah Ort, Finances of the Nation, 2009 (Canadian Tax Foundation, 2010) at p. 5:6.

${ }^{14}$ See Karin Treff and Deborah Ort, Finances of the Nation, 2009 (Canadian Tax Foundation, 2010) at p. 6:2.
} 
This chapter describes the de jure and de facto allocation of taxing powers in the Canadian federation. To this end, Part 2 outlines the constitutional allocation of taxation powers between the federal government and the provincial governments, providing direct references to Canada's principal constitutional text, the Constitution Act, 1867. Part 3 explains how the Canadian courts currently interpret and apply Canada's formal constitutional framework for the allocation of taxing power. Part 4 describes how the different levels of Canadian government administer and continue to modify through political agreement the constitutional allocation of taxation powers in Canada. Part 5 concludes.

\section{The Constitutional Allocation of Taxation Powers}

The Canadian constitution provides the starting point for any discussion of the allocation of the powers of taxation among Canada's governments. Canada's original constitution was passed as an ordinary statute of the Parliament of the United Kingdom in 1867. The Dominion of Canada was established originally with just five constituent governments-the four original provinces (New Brunswick, Nova Scotia, Ontario, and Québec) and Canada's federal government. Six additional provinces were added in the decades following Confederation, the most recent being the province of Newfoundland (now known as Newfoundland and Labrador) in 1949. There are three territories, of which Nunavut is the most recent addition. Nunavut was created in 1999, when the Northwest Territories was partitioned into two separate territories. ${ }^{15}$ The western part of what had earlier been the Northwest Territories retained its name, and the eastern part of the former Northwest Territories became Nunavut.

In 1982, the Canadian constitution was "patriated" from the United Kingdom to Canada, as part of a broader constitutional reform process. The 1982 constitutional reforms witnessed: (i) the constitutional entrenchment of the Charter of Rights of Freedoms (in the Constitution Act, 1982); (ii) the introduction of additional provincial powers over natural resources (section 92A of the Constitution Act, 1867); and (iii) the formal recognition of the commitment by federal government to make equalization payments to redistribute resources inter-provincially (section 36 of the Constitution Act, 1982).

This part sets out the constitutional powers over taxation allocated to the federal government and the provinces. The formal taxation powers of the federal government are outlined first, followed by a description of the provincial powers. The Constitution Act, 1867 outlines the powers of the federal government in section 91 (discussed in Section 2.1, below) and the powers of the provinces in section 92 (discussed in Section 2.2, below). These two statutory provisions (sections 91 and 92) of the Constitution Act, 1867 are the most important elements in the Canadian constitutional allocation of taxation power. There are a number of limits on these powers. The following limits are outlined in Section 2.3: (i) section 53 of the Constitution Act, 1867, which requires that taxation be imposed through legislation (i.e., by the legislature) rather than through regulation (i.e., not by the executive); (ii) section 121 of the Constitution

\footnotetext{
15 The territories are more reliant on the federal government than the provinces for funding and do not have separate constitutional status. Whatever taxation powers the territories have result from the delegation of taxation powers from the federal government.
} 
Act, 1867, which establishes the principle that the governments will allow the free internal movement of goods (i.e., there are no internal customs duties permitted); and (iii) section 125 of the Constitution Act, 1867, which establishes the principle that property held any of the governments is not taxable by the other Canadian governments (i.e., there is no intergovernment taxation of land or property). The limit to the degree of permissible delegation of taxation powers is also discussed. The recognition of a commitment by the federal government to provide equalization payments in the form of transfer payments to underperforming provincial governments is discussed in Section 2.4. Finally, the 1982 amendments to the Constitution Act, 1867 that expanded the ability of provincial governments to collect revenues from the exploitation of natural resources are discussed in Section 2.5.

\subsection{Federal Powers over Taxation}

The powers of the federal government are generally broad. The powers of the federal government are enumerated principally in section 91 of the Constitution Act, 1867. Part VI of the Constitution Act, 1867 is entitled, "Distribution of Legislative Powers." Section 91 provides that:

\section{Powers of the Parliament}

91. It shall be lawful for the Queen, by and with the Advice and Consent of the Senate and House of Commons, to make Laws for the Peace, Order, and good Government of Canada, in relation to all Matters not coming within the Classes of Subjects by this Act assigned exclusively to the Legislatures of the Provinces; and for greater Certainty, but not so as to restrict the Generality of the foregoing Terms of this Section, it is hereby declared that (notwithstanding anything in this Act) the exclusive Legislative Authority of the Parliament of Canada extends to all Matters coming within the Classes of Subjects next hereinafter enumerated; that is to say, -

\section{$[\ldots]$}

3. The raising of Money by any Mode or System of Taxation.

\section{[...]}

And any Matter coming within any of the Classes of Subjects enumerated in this Section shall not be deemed to come within the Class of Matters of a local or private Nature comprised in the Enumeration of the Classes of Subjects by this Act assigned exclusively to the Legislatures of the Provinces.

There are at least three observations to be made regarding this allocation of taxing power to the federal government. The first is that the language is ostensibly unconditional. That is, so long as a measure can fairly be regarded as relating to a "mode or system of taxation," it prima facie is within the scope of the taxation powers allocated to the federal government. Of course, despite the unconditional language it turns out that federal taxing power is not unlimited, and 
most importantly, it should be observed that the taxation power cannot be used to indiscriminately override the exclusive powers allocated to the provinces. ${ }^{16}$

The second observation is that the preamble to section 91 states that the federal government has the power to make laws "for the Peace, Order, and good Government of Canada in relation to all Matters not coming within the Classes of Subjects by this Act assigned exclusively to the Legislatures of the Provinces" (emphasis added). This language can be, and has been, interpreted to provide that the residual claim on law-making power is held by the federal government, and that the powers allocated exclusively to the Provinces are carved out of this more general law-making power. In other words, by default the power to make laws in Canada resides in the federal government.

The third observation is that the section contemplates that there is the potential for overlapping constitutional jurisdiction in taxation matters. The preamble to section 91 states that, "it is hereby declared that (notwithstanding anything in this Act) the exclusive Legislative Authority of the Parliament of Canada extends to all Matters coming within the Classes of Subjects next hereinafter enumerated" (emphasis added). As will be clear from the discussion in Section 2.2 below, there may be certain taxes that fall within both "the Classes of Subjects by this Act assigned exclusively to the Legislatures of the Provinces" and those powers that are "the exclusive Legislative Authority of the Parliament of Canada." Accordingly, there is the potential for overlapping jurisdiction over taxation matters. ${ }^{17}$ A discussion of this issue follows in Parts 3 and 4 below.

\subsection{Provincial Powers over Taxation}

Section 92 of the Constitution Act, 1867 outlines the exclusive powers of the provinces. It provides as follows:

\section{Exclusive Powers of Provincial Legislatures}

92. In each Province the Legislature may exclusively make Laws in relation to Matters coming within the Classes of Subjects next hereinafter enumerated; that is to say, -

\section{$[\ldots]$}

\footnotetext{
${ }^{16}$ Indeed, according to Professor Gerald La Forest (later Justice of the Supreme Court of Canada), "The important question is the extent to which the taxing power may be used as a device for regulating matters falling within the enumerated powers of the provinces. Any tax will almost invariably involve some measure of regulation, and since provincial legislative powers, particularly those over property and civil rights and local or private matters, are so broad federal taxation will almost inevitably affect matters within provincial legislative competence. Parliament must, therefore, be given some leeway in levying taxes. No one has ever suggested that it must tax all persons, activities or commodities at a uniform rate even though differential rates of taxation will influence people in undertaking or refraining from an activity; in fact, differential rates intentionally imposed as tax incentives have never been questioned even when some provinces are preferred over others." See Gerald V. La Forest, The Allocation of the Taxing Power Under the Canadian Constitution, $2^{\text {nd }}$ ed. (Canadian Tax Foundation, 1980) at p. 42.

${ }^{17}$ See Gerald V. La Forest, The Allocation of the Taxing Power Under the Canadian Constitution, $2^{\text {nd }}$ ed. (Canadian Tax Foundation, 1980) at p. 52, who reports that, "Since both levels of government may impose direct taxation and levy revenue by way of licences, their legislation may well overlap."
} 
2. Direct Taxation within the Province in order to the raising of a Revenue for Provincial Purposes.

\section{[...]}

9. Shop, Saloon, Tavern, Auctioneer, and other Licences in order to the raising of a Revenue for Provincial, Local, or Municipal Purposes.

There are a number of observations to make regarding the elements of section 92. The first is that the provision shows through its silence on the matter that the powers allocated to the provinces do not go beyond the powers that are specifically enumerated. The counter-point to the observation that the powers allocated to the federal government to make laws are general in nature is that the enumerated powers are provided as examples of the general federal power over law making rather than an exhaustive account of the legislative powers of the federal government. Limiting the provinces to the specifically enumerated powers is not crippling to the provinces, however, since some of the specifically enumerated powers are very broad. Two of the broadest provincial powers are subsection 92(13), which provides that the provinces have exclusive jurisdiction over "Property and Civil Rights in the Province," and subsection 92(16), which allocates exclusive jurisdiction over "Generally all Matters of a merely local or private Nature in the Province" to the provinces.

A second observation is that the provinces are explicitly allocated by subsection 92(2) the power to impose "Direct taxation within the Province in order to the raising of a Revenue for Provincial Purposes." Section 92 explicitly states that this is an "exclusive power." The suggestion might be taken that there is no scope for the federal government to impose direct taxes in the provinces. This, however, would be to ignore the inherent limitation on the power, which makes it contingent on the taxes being imposed "for Provincial Purposes." It is clearly suggested by this language that it would only be unconstitutional for the federal government to impose direct taxation in order to raise revenue for provincial purposes (and would be constitutional for the federal government to raise revenue through direct taxes for federal purposes, since this would not transgress an "exclusive power" of the provinces). Recall, too, the parenthetical reference in section 91, emphasized above, stating that the federal powers listed applied "notwithstanding anything in this Act." This phrase, read alongside the federal power to use any "Mode or System of Taxation," also suggests that the constitution provides for a parallel or concurrent power held by the federal government and the provinces in the case of direct taxation.

A third observation relating to subsection 92(2) is that it is clear that provinces are not explicitly allocated the power to impose indirect taxes (at least not qua indirect taxes) pursuant to the constitutional allocation of taxation power, even though subsection 92(9) allows for the imposition of licence fees. The provision in 92(9) for the imposition of licence fees sits uneasily alongside the power to impose only direct taxes, since in certain circumstances licence fees might most reasonably be characterized as indirect taxes. As will be seen in Part 3, below, the resulting friction between the two heads of power has led to recurrent litigation. For reasons growing out of the Canadian adherence to UK tax concepts, it also turns out that the prohibition on provincial indirect taxes is, if the province is duly diligent in the legal 
construction of its levy, a loose (and perhaps entirely non-binding) constraint on provincial taxation powers. ${ }^{18}$

\subsection{Limits on Taxation}

The central story flowing from the constitutional allocation of taxing powers from sections 91 and 92 of the Constitution Act, 1867 is that the federal government is entitled to impose essentially all kinds of taxes and provinces are entitled only to impose direct taxes and licence fees. Unsurprisingly, however, there are limits on these powers.

\subsubsection{No Internal Customs Duties}

Section 121 promotes the free flow of goods within Canada. ${ }^{19}$ The Supreme Court of Canada has held that this provision was included originally out of a desire for a common economic market free from internal tariffs or customs duties. ${ }^{20}$ There is not, however, a perfectly integrated internal market in Canada, given provincial powers in producing and regulating electricity markets, regulating certain markets such as that for liquor, and in the operation of provincial procurement policies, which sometimes have favoured provincial interests explicitly.

More recently, in the mid-1990s the premiers of all ten provinces established the Agreement on Internal Trade, $^{21}$ which provides for tighter interprovincial economic integration among provinces. $^{22}$ The agreement establishes general rules for preventing new trade barriers from arising and creates a framework for reducing those already in existence. Further, a formal dispute resolution mechanism was negotiated in order to address possible infractions without needing to resort to the court system, thereby lessening the burden on section 121 to ensure free trade. The Agreement on Internal Trade may also serve as an interpretive aid for the division of powers and section 121. The principle at work in the Agreement on Internal Trade is proportionality, meaning that a valid execution of legislative power that incidentally affects free trade will be upheld so long as the legislative objective does not have a disproportionate impact on the free flow of goods. ${ }^{23}$

\footnotetext{
${ }^{18}$ On the nature of these UK tax concepts, see Benjamin Alarie and David G. Duff, "The Legacy of UK Tax Concepts in Canadian Income Tax Law" [2008] British Tax Review 228.

${ }^{19}$ Section 121 of the Constitution Act, 1867 provides that, "121. All Articles of the Growth, Produce, or Manufacture of any one of the Provinces shall, from and after the Union, be admitted free into each of the other Provinces." For an extended discussion of this provision, see See Gerald V. La Forest, The Allocation of the Taxing Power Under the Canadian Constitution, $2^{\text {nd }}$ ed. (Canadian Tax Foundation, 1980) at pp. 178-182.

${ }^{20}$ In Gold Seal Ltd. v. Attorney-General of Alberta (1921), 62 S.C.R. 424, Duff J. of the Supreme Court of Canada stated that, "the real object of the clause is to prohibit the establishment of customs duties affecting interprovincial trade in the products of any province of the Union."

${ }^{21}$ For scholarly treatments of the Agreement on Internal Trade, see Michael J. Trebilcock and Daniel Schwanen, eds., Getting There: An Assessment of the Agreement on Internal Trade (Toronto: C.D. Howe Institute, 1995), and G. Bruce Doern and Marc MacDonald, Free-Trade Federalism: Negotiating the Canadian Agreement on Internal Trade (University of Toronto Press, 1999).

${ }^{22}$ See Industry Canada, "Agreement on Internal Trade" http://www.ic.gc.ca/eic/site/ait-aci.nsf/eng/home

${ }^{23}$ See George Vegh, "The Characterization of Barriers to Interprovincial Trade Under the Canadian Constitution" (1996) 34 Osgoode Hall L.J. 355-410.
} 


\subsubsection{No Inter-Governmental Taxation}

Section 125 provides a further limitation that applies to both the federal government and the provinces. The section provides that,

125. No Lands or Property belonging to Canada or any Province shall be liable to Taxation.

The significance of this section is that it constitutionally establishes and supports the equal stature of the federal Parliament and the provincial legislatures. The prevailing idea is that the federal Parliament and the provincial legislatures should be equally free within their own legislative competencies to hold property free from incursion by other Canadian governments. If the provinces, for example, are made subject to the unlimited federal taxation power, even if only through a land or property tax, the power of the provinces could be radically curtailed by the federal government. Correspondingly, if the provinces could impose direct taxes on the federal government's presence in each of the provinces, the balance of powers between the provinces and the federal government would be in jeopardy. Section 125 therefore strives to set as the constitutional default a presumption of no inter-governmental taxation of land and property. ${ }^{24}$ Despite this general approach, in practice both federal and provincial governments usually pay 'payments-in-lieu' (grants) to municipalities to offset the exemption of their properties from local taxation, albeit on different bases. ${ }^{25}$

\subsubsection{Democratic Taxation}

Limits to taxation are not restricted to substantive issues. Section 53 of the Constitution Act, 1867, adds an important procedural limitation, and reads as follows:

53. Bills for appropriating any Part of the Public Revenue, or for imposing any Tax or Impost, shall originate in the House of Commons.

This section serves as a manifestation of the constitutional principle that there should be no taxation without representation. The effect of the section is that only a majority of an elected body can introduce a tax. Similar to the rationale for depriving provinces of indirect taxation, section 53 ensures that no measures of taxation can be introduced without the clear consent of elected representatives through a transparent process. The section takes on its most important role in circumscribing the means by which governments may raise revenue through regulation and licensing, discussed in detail below.

\footnotetext{
${ }^{24}$ For an extensive discussion of section 125, see Gerald V. La Forest, The Allocation of Taxing Power Under the Canadian Constitution, $2^{\text {nd }}$ edition (Canadian Tax Foundation, 1981) at pp. 182-186.

${ }^{25}$ See Harry M. Kitchen, Local Government Finance in Canada (Canadian Tax Foundation, 1984) at p.227. See also Karin Treff and Deborah Ort, Finances of the Nation, 2009 (Canadian Tax Foundation, 2010) at 6:10 to 12 and 7:8 and 7: 12 .
} 


\subsubsection{Delegation}

In a country of Canada's geographical size (it is the second largest nation-state by area with 9.8 million $\mathrm{km}^{2}$ ), effective government would be made inordinately difficult if the legislatures did not have the ability to delegate power. There was initial uncertainty about the permissible scope of delegation powers in Canada. Since both the federal Parliament and the provincial legislatures were created by an Act of the UK Parliament, some argued that they could not further delegate power given the doctrine of delegatus non potest delegare ("A delegate has no power to delegate"). The UK Judicial Committee of the Privy Council (JCPC) in Hodge v. The Queen, ${ }^{26}$ however, removed all doubt about the permissibility of the delegation of power, declaring that provincial legislative power was "as plenary and as ample within the limits prescribed by section 92 as the Imperial Parliament in the plenitude of its power possessed and could bestow." 27 The Privy Council also explained that the federal Parliament possessed the same degree of power to delegate its own powers. ${ }^{28}$ The federal government has since exercised this delegation power in ceding various powers to the three territories of the Yukon, the Northwestern Territories, and Nunavut, since the territories do not have the constitutional status of provinces and therefore have the powers delegated to them from the federal government.

With the expansive power of delegation, the task of raising revenue has been vested in a number of subordinate entities, ranging from licensing boards to municipal governments. For our purposes, the most significant restrictions on the powers of delegation are section 53 of the Constitution Act, 1867, discussed above, and the critical fact that legislatures can only delegate the power they themselves possess. The case law in Part 3, below, demonstrates that these issues have from time to time been controversial.

\subsection{Equalization Payments}

The Constitution Act, 1982, Schedule B, which was introduced during Canada's 1982 constitutional reforms, recognizes the obligation of the federal government to exercise its greater taxation capacity to make equalization payments to the provinces, in order "to provide reasonably comparable levels of public services at reasonably comparable levels of taxation." The provision states that:

36. (1) Without altering the legislative authority of Parliament or of the provincial legislatures, or the rights of any of them with respect to the exercise of their legislative authority, Parliament and the legislatures, together with the government of Canada and the provincial governments, are committed to

(a) promoting equal opportunities for the well-being of Canadians;

(b) furthering economic development to reduce disparity in opportunities; and

\footnotetext{
${ }^{26}$ (1883) 9 App.Cas. 117 (JCPC); [1883] J.C.J. No. 2 (QL).

${ }^{27}$ Ibid at para. 36.

${ }^{28} \mathrm{Ibid}$ at paras. $36-37$.
} 
(c) providing essential public services of reasonable quality to all Canadians.

(2) Parliament and the government of Canada are committed to the principle of making equalization payments to ensure that provincial governments have sufficient revenues to provide reasonably comparable levels of public services at reasonably comparable levels of taxation.

Although the meaning of "reasonably comparable levels of taxation" has to date not been tested by the courts, the issue of equalization payments is an important part of the political adaptation to the allocation of taxation powers in Canada. ${ }^{29}$ For this reason, it is discussed in more detail in Part 4, below.

\subsection{The Special Treatment of Natural Resources}

Adjustments to the Canadian Constitution in 1982 most prominently featured the inclusion of a Charter of Rights and Freedoms, but it also provided for slight modifications to the allocation of taxing powers under the Constitution Act, 1867. One of the most notable of these changes is the introduction of section 92A in the amended Constitution Act, 1867. Pursuant to this section, provinces were given complete and exclusive control over natural resources within provincial borders. Most significantly for our purposes, this section includes section 92A(4)(a), which reads

92A. [...]

(4) In each province, the legislature may make laws in relation to the raising of money by any mode or system of taxation in respect of

(a) non-renewable natural resources and forestry resources in the province and the primary production therefrom ${ }^{30}$

Section 92A therefore grants to the provinces the power to tax natural resources by whatever means are available, including both indirect and direct taxation. As discussed below, however,

\footnotetext{
${ }^{29}$ It remains to be seen conclusively whether section 36 can be used to justify a right to receive equalization payments from the federal government. A discussion of this issue appears in Aymen Nader, "Providing Essential Services: Canada's Constitutional Commitment Under Section 36" (2003) 19 Dalhousie Law Journal 306. It has been found by the Nova Scotia Court of Appeal that municipalities may not invoke section 36 to justify a claim for equitable disbursement of equalization payments vis-à-vis the province in Cape Breton (Regional Municipality v. Nova Scotia (Attorney General), 2009 NSCA 44. The court made the following remarks in addressing the role of section 36:

[The section] codifies an agreement among the federal and provincial governments respecting the principles of equalization and the redress of regional disparities. The standards in paras. (a), (b) and (c) of s. 36(1), including the references to opportunities, well-being and reasonable public services to Canadians, are the benchmarks of the commitments among the federal and provincial governments. Whether the federal or provincial governments could sue, or maintain a justiciable cause of action, inter se for a violation of these standards is not an issue in this appeal. So I express no view on that matter. The point that is relevant here is that the constitutional privity to the agreement that is codified in s. 36 rests with the federal and provincial governments, not with individual Canadians or municipalities.

${ }^{30}$ Section 92A, Part II of the Constitution Act, 1982, being Schedule B to the Canada Act 1982 (U.K.), 1982, c.11
} 
section 92A does not prevent the Parliament from passing laws that affect natural resources as long as the pith and substance of this legislation is within the jurisdiction of the federal government. ${ }^{31}$ The territories are, of course, in a different position, because they lack the same constitutional status as provinces.

\section{Litigation on the Exercise of Taxation Powers}

Given the centrality of revenue collection to the sustenance of government, and the fact that taxes pit taxpayers' own economic interests directly against those of government, it is perhaps not surprising that there has been repeated litigation over the constitutional validity of various tax laws and regulations throughout Canada's history. Attacks on the constitutionality of taxes have typically taken one of three forms. The first type of claim is that a levy imposed by a province is actually an indirect tax and is not saved as being a permissible licence fee under 92(9). Such a levy would be unconstitutional because it would lie beyond the taxation powers of the provinces. The second type of claim is that a levy is a tax and that it has been imposed through regulation rather than through legislation, thereby violating section 53 of the Constitution Act, 1867; this second type of claim has been made against both the federal government and provincial governments. The third type of claim is that a particular levy is invalid because it constitutes a tax on property belonging to the federal or provincial governments, contrary to section 125 of the Constitution Act, 1867.

\subsection{Distinction between Direct and Indirect Taxation}

The most famous articulation of the distinction between direct and indirect taxation is attributed to the English philosopher and polymath, J.S. Mill. In 1848, in his Principles of Political Economy, Mill explained that:

Taxes are either direct or indirect. A direct tax is one which is demanded from the very persons who, it is intended or desired, should pay it. Indirect taxes are those which are demanded from one person in the expectation and intention that he shall indemnify himself at the expense of another: such as the excise or customs. The producer or importer of a commodity is called upon to pay tax on it, not with the intention to levy a peculiar contribution upon him, but to tax through him the consumers of the commodity, from whom it is supposed that he will recover the amount by means of an advance in price.

Direct taxes are either on income or on expenditure. Most taxes on expenditure are indirect, but some are direct, being imposed, not on the producer or seller of an article, but immediately on the consumer. A house-tax, for example, is a direct tax on expenditure, if levied, as it usually is, on the occupier of the house.

\footnotetext{
${ }^{31}$ See, for example, Friends of Oldman River Society v. Canada (Minister of Transport), [1992] 1 S.C.R. 3, where the Supreme Court of Canada ruled that environmental regulation fell within Parliament's authority to legislate for the "Peace, Order, and Good Government of Canada" and could therefore incidentally intrude upon the province's jurisdiction over natural resources.
} 
If levied on the builder or owner, it would be an indirect tax. A window-tax is a direct tax on expenditure; so are the taxes on horses and carriages. ${ }^{32}$

From the earliest cases, the courts have held that Mill's articulation of the distinction between a direct tax and an indirect tax would have been the understanding of the parties that negotiated the allocation of taxation powers under the Canadian constitution. ${ }^{33}$ Indeed, parts of Mill's passage have been quoted with approval by the Supreme Court of Canada on a number of occasions. ${ }^{34}$ Further support of this contention comes from the comments of Viscount Simon of the Judicial Committee of the Privy Council (JCPC) in Atlantic Smoke Shops Limited v. Conlon, ${ }^{35}$

It has been long and firmly established that, in interpreting the phrase "direct taxation" in head 2 of section 92 of the Act of 1867 [Constitution Act, 1867], the guide to be followed is that provided by the distinction between direct and indirect taxes which is to be found in the treatise of John Stuart Mill. The question, of course, [...] is not what is the distinction drawn by writers on political economy, but in what sense the words were employed in the British North America Act [Constitution Act, 1867]. Mill's Political Economy was first published in 1848, and appeared in a popular edition in 1865. Its author became a member of parliament in this latter year and commanded much attention in the British House of Commons. Having regard to his eminence as a political economist in the epoch when [...] the Act of 1867 [Constitution Act, 1867] was being framed, the use of Mill's analysis and classification of taxes for the purpose of construing the expression now under review is fully justified. ${ }^{36}$

Despite the consensus that the constitution adopts Mill's view of direct and indirect taxes, the distinction between what constitutes a direct tax and what constitutes an indirect tax has been a frequently contested one that has given rise to sporadic and inconsistent treatment by the courts.

This mixed treatment can be accounted for in large part by three contributing factors. The first factor is that the distinction between direct and indirect taxes is a false dichotomy. Most taxes

\footnotetext{
${ }^{32}$ See John Stuart Mill, Principles of Political Economy (1848), Chapter 2, §1.

${ }^{33}$ For a discussion of the earliest cases, and especially Bank of Toronto v. Lambe (1887), 12 A.C. 575, see Gerald V. La Forest, The Allocation of Taxing Power Under the Canadian Constitution, $2^{\text {nd }}$ ed. (Canadian Tax Foundation, 1981) at pp. 78-80.

${ }^{34}$ See, for example, Reference re: Grain Futures Taxation Act (Manitoba), [1924] S.C.J. No. 14; Fairbanks Estate v. Halifax (City), [1926] S.C.J. No. 19; Canadian Industrial Gas \& Oil Ltd. v. Saskatchewan, [1977] S.C.J. No. 124; Javelin International Ltd. v. Newfoundland (Attorney General), [1982] S.C.J. No. 68; Allard Contractors Ltd. v. Coquitlam (District), [1993] S.C.J. No. 126; and Ontario Home Builders' Assn. v. York Region Board of Education, [1996] S.C.J. No. 80.

${ }^{35}$ [1943] A.C. 553 (JCPC).

${ }^{36}$ Ibid at p. 563.
} 
in reality have mixed and empirically uncertain incidence. ${ }^{37}$ The second contributing factor is that courts are sometimes willing to find provincial taxes to be indirect taxes when, commentators are led to suspect, the courts find the impugned taxes substantively unattractive for reasons having little to do with the "directness" or "indirectness" of a particular tax. A third factor is that, following the UK courts, Canadian courts have been heavily influenced by the "legal substance" of taxation measures much more than the "economic substance" of tax measures. ${ }^{38}$ Since the direct and indirect distinction is one of economic substance rather than legal substance, the Canadian courts have struggled to make the distinction consistently.

The courts have generally accepted that the distinction between direct and indirect taxes exists more as an issue of legal characterization than economic reality, and should therefore be applied to facts according to the "general understanding of men" rather than according to the actual effects of any particular taxation measure. Customs duties, for example, are traditionally understood to be indirect taxes, and this is typically reflected empirically, yet market conditions may at times result in importers bearing most of the incidence of these duties. In spite of circumstances that may violate the assumption that the incidence of customs duties is on the ultimate consumer, Canadian courts typically consider customs duties to be indirect taxes for the sake of predictability and consistency. ${ }^{39}$

Given the limited scope of this chapter, it is appropriate to explain generally the way in which the Canadian courts have put into operation Mill's distinction between direct taxes and indirect taxes, with resort to only a few of the central cases for the purposes of illustration of the problems encountered.

\subsubsection{Levies Held to be Direct Taxes}

The Canadian courts have recognized the fact that most direct taxes will in part be borne by a party other than the taxpayer. Nevertheless, the courts have felt obliged to give substantive content to the constitutional distinction between direct and indirect taxes. The distinction between direct and indirect taxes is preserved by considering not the ultimate economic incidence of a tax, but the legal form of the taxes imposed and the ostensible intention of the legislators as to the identity of the targeted taxpayer. This distinction animates the following cases, where a tax was held to be direct, and is consistent with the broad approach of the Canadian and UK courts in income tax cases, where legal substance frequently triumphs over economic substance. ${ }^{40}$

\footnotetext{
37 See, for example, "Chapter 16: The Theory and Measurement of Tax Incidence" in Richard W. Tresch, Public Finance: A Normative Theory, $2^{\text {nd }}$ ed. (San Diego: Elsevier Science, 2002), at pp. 524-571.

38 See Benjamin Alarie and David G. Duff, "The Legacy of UK Tax Concepts in Canadian Income Tax Law" [2008] British Tax Review 228-252.

${ }^{39}$ See Gerald V. La Forest, The Allocation of Taxing Power Under the Canadian Constitution, $2^{\text {nd }}$ ed. (Canadian Tax Foundation, 1981) at pp. 195.

40 See Benjamin Alarie and David G. Duff, "The Legacy of UK Tax Concepts in Canadian Income Tax Law" [2008] British Tax Review 228-252.
} 
The earliest case holding that a given levy constituted a direct tax was the Bank of Toronto $v$. Lambe. ${ }^{41}$ In this case, the Province of Québec required every bank that operated or carried on business in that province to pay a tax that varied with the bank's paid-up capital, with an additional levy payable for each place of business. The JCPC held that the levy was valid on the basis that the tax was a direct tax. The JCPC rejected the contention of the bank that it would have been expected to recover the cost of the levy from the firm's customers. The court held that although there would be "passing on" the economic cost of the tax, "it appears to their Lordships that the Quebec legislature must have intended and desired that the very corporations from whom the tax is demanded should pay and finally bear it. It is carefully designed for that purpose. It is not like a customs' duty which enters at once into the price of the taxed commodity. There the tax is demanded of the importer, while nobody expects or intends that he shall finally bear it." 42

Another of the early cases finding a taxation measure to be a direct tax is Brewers' and Maltsters' Association v. Attorney-General of Ontario. ${ }^{43}$ In this case, the JCPC concluded that a uniform licence fee of $\$ 100$ imposed by the Province of Ontario on every brewer and distiller was "a uniform fee of a trifling amount" and that it "cannot have been intended by the imposition of such a burden to tax the customer or consumer." Instead, the JCPC explained that,

In the present case, as in Lambe's Case, 12 App. Cas. 575, their Lordships think the tax is demanded from the very person whom the Legislature intended or desired should pay it. They do not think there was either an expectation or intention that he should indemnify himself at the expense of some other person. No such transfer of the burden would in ordinary course take place or can have been contemplated as the natural result of the legislation in the case of a tax like the present one, a uniform fee trifling in amount imposed alike upon all brewers and distillers without any relation to the quantity of goods which they sell. It cannot have been intended by the imposition of such a burden to tax the customer or consumer. It is of course possible that in individual instances the person on whom the tax is imposed may be able to shift the burden to some other shoulders. But this may happen in the case of every direct tax. ${ }^{44}$

Another example of a finding that a tax was valid as a direct tax is the case of Atlantic Smoke Shops Limited v. Conlon. ${ }^{45}$ In this case, the province of New Brunswick had imposed a sales tax of $10 \%$ of the retail price of tobacco products. The tax was to be collected from the retail purchaser by the vendor, and remitted to the province by the vendor. Atlantic Smoke Shops Limited challenged the levy as an indirect tax outside of the jurisdiction of the province. The JCPC found that the tobacco sales tax was actually a direct tax, since it was expected and

${ }^{41}$ (1897), 12 App.Cas. 575 (JCPC); [1887] J.C.J. No. 1 (QL).

${ }^{42}$ Ibid at para. 11.

${ }^{43}$ [1897] A.C. 213 (JCPC); [1897] J.C.J. No. 1 (QL).

${ }^{44} \mathrm{Ibid}$ at para. 10.

${ }^{45}$ [1943] A.C. 553 (JCPC); [1943] J.C.J. No. 1 (QL). 
intended that the final purchaser of a retail item would be the one to bear the cost of the tax, even though the tax was, out of administrative convenience, to be collected by the vendor. According to Viscount Simon,

...[I]t would be more accurate to say that a sales tax is indirect when in the normal course it can be passed on. If a tax is so devised that (as Mill expresses it) the taxing authority is not indifferent as to which of the parties to the transaction ultimately bears the burden, but intends it as a "peculiar contribution" on the particular party selected to pay the tax, such a tax is not proved to be indirect by calling it a sales tax. ${ }^{46}$

The key factor in this formulation appears to be one of legal substance, and not mere nomenclature on the one hand (i.e., using the label of "sales tax" does not dictate a result that the tax is indirect). ${ }^{47}$ Moreover, it is also clear that the true economic incidence of the tax is not relevant; there is no inquiry into the elasticity of supply or demand for the relevant tobacco products. Instead, what matters is that the ultimate consumer must legally pay the tax, and that the intermediating retailers are treated merely as agents of the government in collecting and remitting the tax. Indeed, the main lesson to be drawn from these cases is that mere nomenclature and economic substance are not at all decisive in the determination of whether a particular tax is direct (or indirect). If the legal substance of a levy can reasonably be regarded as one of direct taxation, then the Canadian courts will tend to regard the imposition as direct taxation. $^{48}$

\subsubsection{Levies Held to be Indirect Taxes}

Despite the relative ease with which it appears from the Atlantic Smoke Shops Limited v. Conlon decision that indirect taxes can be legally structured as direct taxes for the purposes of surviving constitutional scrutiny, there are a number of cases in which provincial levies have been found to be ultra vires on the basis that they are indirect taxes.

In Canadian Industrial Gas \& Oil v. Government of Saskatchewan et al., ${ }^{49}$ the Supreme Court of Canada considered the appropriate characterization of a tax instituted by the province of Saskatchewan. The measure required oil producers to pay a tax equal to one hundred percent of the revenues in excess of the "basic well-head price" that was set by statute and was a price roughly equivalent to the oil price that prevailed before the energy crises of the early 1970s. Of course, because the tax was confiscatory above the statutorily set price, an anti-avoidance

\footnotetext{
${ }^{46}$ Ibid at para. 5.

47 On the insufficiency of labels or mere nomenclature, see the case of City of Charlottetown v. Foundation Maritime Ltd., [1932] S.C.R. 589, where the Supreme Court of Canada remarked at p. 593 that, "The [impugned] by-law declares that the tax is to be a 'direct' one, but it is needless to say that the point does not turn on the language used in the enactment. As was observed in Caledonian Collieries Limited v. The King, to label the tax as a direct tax does not affect the substance of the matter."

${ }^{48}$ See, for example, Cotton v. The King, [1914] A.C. 176; Forbes v. Attorney-General of Manitoba, [1937] A.C. 260, Clarke v. City of Moose Jaw, [1923] 2 D.L.R. 216; and Re National Trust Co. and Toronto, [1931] 4 D.L.R. 355.

${ }^{49}$ [1978] 2 S.C.R. 545 (SCC).
} 
provision was necessary. The anti-avoidance rule stipulated that if the Minister considered the final sale price to be below the fair market value of the oil, then the tax would be calculated based on a presumption that the sales price of the oil was equal to its fair market value instead of the actual price received.

An obvious argument to justify the levy as a direct tax is that the vendors of the oil would be paying a tax equal to the difference between the statutorily set price and the market price regardless of the actual price paid by the purchaser. From this perspective, it could not be clearer that the tax was not going to be recovered by the seller from the purchaser. The majority of the Supreme Court of Canada rejected this argument. Justice Martland held the tax to be indirect, and therefore outside the province's legislative competence. The majority's decision states that:

...the true effect of the legislation is to impose a freeze upon the actual income which the producer exporter can derive from the sale of his product. All that he is permitted to retain on the sale of each barrel of oil is the basic well-head price. In addition to being subjected to an income freeze, he is compelled to sell his product at a price equivalent to what the Minister considers to be its fair value in order to obtain the funds necessary to meet the tax. This amount per barrel over and I above the basic well-head price he must obtain from his purchaser as a part of the purchase price. In essence the producer is a conduit through which the increased value of each barrel of oil above the basic well-head price is channelled into the hands of the Crown by way of tax. The increase in value is itself the tax and it is paid by the purchaser of the oil.

It is contended that the imposition of these taxes will not result in an increase in the price paid by oil purchasers, who would have been required to pay the same market price even if the taxes had not been imposed, and so there could be no passing on of the tax by the Saskatchewan producer to his purchaser. On this premise it is argued that the tax is not indirect. This, however, overlooks the all important fact that the scheme of the legislation under consideration involves the fixing of the maximum return of the Saskatchewan producers at the basic well-head price per barrel, while at the same time compelling him to sell at a higher price. There are two components in the sale price, first the basic wellhead price and second the tax imposed. Both are intended by the legislation to be incorporated into the price payable by the purchaser. The purchaser pays the amount of the tax as a part of the purchase price. ${ }^{50}$

It is difficult to make sense of this decision from an economic perspective. For one thing, the Court seems to have ignored the fact that many producers of oil would have been selling into Saskatchewan, so that the Saskatchewan consumers were faced with perfectly substitutable oil from those subject to the tax and those not subject to the tax. There is little reason to think

\footnotetext{
${ }^{50}$ Ibid at p. 566.
} 
that the Saskatchewan producers would have been able to pass on the higher price to purchasers. Moreover, Saskatchewan producers would have been selling oil to purchasers outside the province as well; there is no reason to believe that purchasers outside of the province would be willing to pay more than the prevailing market price for oil in their markets, either. The tax imposed by the province of Saskatchewan is economically equivalent to seizing a fraction of the oil sold that leaves enough for the producer to recover per barrel the pre-crisis market price of the oil.

In Simpson-Sears Ltd. v. Provincial Secretary for New Brunswick et al., ${ }^{51}$ the Court considered a provincial tax on the distribution of mail-order catalogues. Even though the catalogues were distributed for free to potential consumers, the Supreme Court of Canada ruled 5-4 that the tax was indirect and therefore ultra vires the province. Even though the costs of the tax would not be passed on to the consumer in a direct way, the court quoted the following passage from the judgment in Canadian Industrial Gas \& Oil v. Government of Saskatchewan et al. as the basis of its decision:

The dividing line between a direct and an indirect tax is referable and ascertainable by the "general tendencies of the tax and the common understanding of men as to those tendencies."... The general tendency of a tax is the relevant criterion. ${ }^{52}$

In decisions such as these, the key factor is seen once again legal substance rather than economic substance. Thus, there must be the expectation on the part of the tax's drafters that the taxed entity should recover the costs by passing on the cost through its sales. While "passing on" is often indicative of an indirect tax, it is neither necessary nor sufficient. The actual test that the Canadian courts use, it is suggested, is one of legal substance inferred from the law on its face and the apparent legislative intent.

\subsubsection{The Approach of the Canadian Courts}

The crux of the Canadian approach to the direct/indirect taxation distinction lies in the extent to which the legislature has a particular taxpayer in mind. Characterized as the "general tendency," courts must interpret the statute's language and determine upon whom the tax burden was intended to fall, if anyone. For direct taxes, the specificity of the identity of the taxpayer is an important consideration. A direct sales tax must be explicitly aimed at a certain class of persons: the consumer. For most other direct taxes, such as income taxes, the legislature must intend that the persons or entities paying are the targets of the tax, regardless of whether they are able ultimately to recoup their expenditures through the general operations of business. For example, it appears to matter little that as a legal fiction, corporations must eventually recover all income taxes from individual employees, shareholders, customers, or other stakeholders.

${ }^{51}[1978] 2$ S.C.R. 869 (SCC).

52 lbid. at p. 889. 
For indirect taxes, meanwhile, the key indicia are whether there is a general tendency for "passing on" and legislative indifference as to the final payer. The legislature must collect from one entity with the intention that the payer will generally pass on the tax to another party, most typically the consumer. Most importantly, so long as the indirect tax has the "general tendency" to be passed on, as understood by the law's makers and the court, then the precise economic incidence is irrelevant.

This analysis renders the distinction often difficult to predict, and "general tendency" is therefore more a term of art than a scientific legal tool. Professor La Forest, as he then was, wrote of the taxes at issue in Simpson-Sears:

The taxes in Lambe's case... and in countless others had similar tendencies. Any tax on a commercial enterprise will have a tendency to be recovered from its customers, and that is surely the common understanding of men. If [the view articulated in Simpson-Sears] prevails, it means that there is no real test to predict the nature of a new tax, except possible, on the basis of the cases, that in indirect taxes, there will usually be a close connection between the transaction taxed and that by which the person upon whom the person taxed recoups himself from the person who ultimately bears the burden of the tax. ${ }^{53}$

This may be an overly dim view of the approach taken, since the majority of taxes fall in close proximity to the ideal types of direct and indirect taxation. Nevertheless, the Canadian approach to the distinction creates fuzzy boundaries where judicial discretion plays a determinative role in the kind of cases that would see a courtroom.

Arguably the most significant difficulty with the Canadian approach is "colourability" of a measure. The characterization of a given levy often boils down to semantics rather than to transparent governing principles. This is perhaps best illustrated by the case of Kingstreet Investments Ltd. v. New Brunswick (Department of Finance), [2007] 1 S.C.R. 3. In Kingstreet Investments, the issue in question was a levy raised by the New Brunswick Liquor Corporation on the sale of alcohol in the petitioners' nightclubs. The levy, as a percentage of sales price, was deemed by the Supreme Court of Canada to be an indirect tax since it was being passed on to the consumer, and it was therefore ultra vires the provincial legislature. As a remedy, the Court held that the government was obligated to refund the full amount of taxes paid previously by the petitioners, plus interest. Instead of paying the back taxes with interest in accordance with the judgment, the province decided to pass retroactive legislation charging the nightclub proprietors a direct tax exactly equal to the amount of indirect taxes that had been found to have been unconstitutionally collected. With a stroke of the pen, the New Brunswick legislature transformed an indirect tax into a direct one, thereby relegating the years of litigation to de facto irrelevance. It could of course be argued in a subsequent challenge to the new legislation that it facilitates New Brunswick doing indirectly what could not be done directly, but the

\footnotetext{
${ }^{53}$ See Gerald V. La Forest, The Allocation of Taxing Power Under the Canadian Constitution, 2nd ed. (Canadian Tax Foundation, 1981) at p. 83.
} 
Canadian courts' adherence to legal substance in matters of taxation seems, as a matter of fact, to have deterred subsequent court challenges. ${ }^{54}$ Indeed, the outcome in Kingstreet Investments seems to be justified by the outcome in Atlantic Smoke Shops v. Conlon, discussed above, where the court held that treating the intermediating retailer as an agent for the collection of tax from the retail consumers was sufficient to regard a tax as direct.

\subsection{Licence Fees}

While direct and indirect taxes comprise the lion's share of both federal and provincial revenues, other means to raise revenues are also available to the provinces. Subsection 92(9) permits the provinces to create licensing schemes for the purposes of raising revenue, although the wording and subsequent interpretation of the clause have led to numerous controversies.

The criteria for what constitutes a tax was first introduced in Lawson v. Interior Tree Fruit and Vegetable Committee of Direction, ${ }^{55}$ where Duff J., as he then was, introduced four criteria that define a tax. A tax must be be: (i) enforceable by law; (ii) imposed under legislative authority; (iii) imposed by a public body; and (iv) intended for a public purpose. ${ }^{56}$ In Re Eurig Estate, ${ }^{57}$ Major J. stated that, "Another factor that generally distinguishes a fee from a tax is that a nexus must exist between the quantum charged and the cost of the service provided." 58 This interpretation allows section 92(9) to play a role distinct from section 92(2), while not rendering the latter meaningless by providing carte blanche to impose indirect taxation.

As a preface to the main issues, two background notes are necessary. First, the JCPC has concluded that the term "other licences" in section 92(9) should not necessarily be limited to the specifically enumerated licences, thereby rendering the power relatively unrestricted in terms of the types of businesses that can be subject to a licensing scheme. ${ }^{59}$ Second, the JCPC also ruled that the provincial power over trade regulation is not to be found in section 92(9), but must instead be combined with another head of power, namely ss. 92(13) (property and civil rights) and 92(16) (matters of a local nature). As such, the licensing power enables provinces to fund regulatory schemes in ways that would not be permitted by section 92(2), but does not serve as an independent source of authority for such schemes. This will be discussed further below with respect to the case law.

\footnotetext{
${ }^{54}$ This is recognized by La Forest, who remarks that, "In a federation where the local governments have such broad powers as they do under the Canadian Constitution, it is imperative that they also have broad fiscal powers. This is now the case in Canada, because judicial interpretation of direct taxation has given the provinces an almost unlimited power to levy any taxes except customs and those raising fiscal walls between the provinces or having primary impact outside the taxing province." See Gerald V. La Forest, The Allocation of Taxing Power Under the Canadian Constitution, 2nd ed. (Canadian Tax Foundation, 1981) at p. 199.

55 [1930] S.C.R. 357.

56 Ibid at pp. 361-362.

57 [1998] 2 S.C.R. 565.

58 Ibid at para. 21.

59 In Brewers' and Maltsters' Association v. Attorney-General of Ontario, [1897] A.C. 213 (JCPC); [1897] J.C.J. No. 1 $(Q L)$, the JCPC reported at para. 12 that it did, "not doubt that general words may be restrained to things of the same kind as those particularised, but they are unable to see what is the genus which would include "shop, saloon, tavern" and "auctioneer" licences and which would exclude brewers' and distillers' licences."
} 
Constitutional challenges most often arise when provinces seek to circumvent constitutional restrictions (most frequently regarding indirect taxation) under the guise of licensing provisions. One of the earliest cases was Attorney-General of Québec v. Queen Insurance Co. (1878), 3 A.C. 1090, where the JCPC considered provincial legislation that ostensibly created a licensing scheme for insurance providers. Pursuant to the Act, insurers needed to secure a licence, the fee for which was a percentage of the premium for each new policy. The JCPC rejected the idea that this was in legal substance a licence, and instead characterized it as an indirect tax, since the amount of the tax would be expected to be largely passed on to the consumer at the start of each policy. In effect, the JCPC emphasized that the pith and substance of the impugned legislation was an attempted exercise of the provincial taxation power, and not merely the exercise of the province's authority to create licensing schemes. The JCPC's conclusion was supported by the fact that no fee was imposed for the issuance of the licence, there was no penalty for failing to obtain one, and policies issued by unlicenced insurers remained valid.

The decision of the JCPC in the Queen Insurance Co. case notwithstanding, a characterization of indirect taxation has not always been fatal. In Reference re Farm Products Marketing Act, ${ }^{60}$ the Supreme Court of Canada considered a provincial marketing scheme that included a licensing requirement for producers. Like Queen Insurance Co., the fee was calculated based on the amount of the marketed good supplied by each producer, and this was characterized by the Court as an indirect tax. The difference, however, lay in the fact that the overall licensing scheme was valid, and the Court ruled that an indirect tax could be used to support a genuine application of section $92(9) .^{61}$

This approach has been followed more recently in Allard Contractors Ltd. v. Coquitlam (District), [1993] 4 S.C.R. 371, where the Court ruled that a licensing fee constituting indirect taxation did not offend the constitution if "it is supportable as ancillary or adhesive to a valid regulatory scheme." ${ }^{62}$ In other words, indirect taxation is not unconstitutional so long as it is necessarily incidental to an otherwise constitutional exercise of authority. This, however, is subject to the restriction discussed earlier in Re Eurig Estate, that the fee must be reasonably tailored to the requirements of the regulatory scheme itself. ${ }^{63}$ It has also been suggested that when delegated to municipalities, the licensing power allows for significant revenue collection, extending

\footnotetext{
${ }^{60}$ [1957] S.C.R. 198.

${ }^{61}$ See also Ontario (Attorney General) v. Canada (Attorney General) (1913), 38 S.C.R. 331.

${ }^{62}$ Of course, to be 'supportable as ancillary or adhesive to a valid regulatory scheme,' the regulatory scheme itself must be valid. The case law has identified a number of relevant factors, including: (i) a complete and detailed code of regulation; (ii) a specific regulatory purpose that seeks to affect the behavior of individuals; (iii) actual or properly estimated costs of the regulation; and (iv) a relationship between the regulation and the person being regulated. None of these factors is necessary or sufficient and the list is not exhaustive. See Westbank First Nation v. British Columbia Hydro and Power Authority, [1999] 3 S.C.R. 134; and 620 Connaught Ltd. v. Canada (Attorney General), [2008] 1 S.C.R. 131.

${ }^{63}$ See also Ontario Home Builders' Association v. York Region Board of Education, [1996] 2 S.C.R. 929; Allard Contractors Ltd. v. Coquitlam (District), [1993] 4 S.C.R. 371 ("A surplus itself is not a problem so long as the municipalities made reasonable attempts to match the fee revenues with the administrative costs of the regulatory scheme....")
} 
beyond the fiscal requirements of the licensing scheme itself. ${ }^{64}$ There is no recent case law on the issue, and it would be interesting to see if this interpretation survives given the subsequent developments in cases such as Re Eurig Estate.

Even if a regulatory charge is characterized by a court as an intra vires form of taxation, there remains one further obstacle. In Confédération des Syndicats Nationaux v. Canada (Attorney General), ${ }^{65}$ the Supreme Court of Canada considered levies collected through the federal Employment Insurance Act. Although the levies were declared to constitute payroll taxes as opposed to regulatory charges, they could still fall under the expansive federal taxation powers. Nevertheless, the Court held that the levies contravened section 53 of the Constitution Act, 1867, which requires that all impositions of a tax must originate in the House of Commons. This could have significance for provinces that might seek to mask direct taxes in the form of regulatory charges for political purposes. ${ }^{66}$

The tax in Confédération des Syndicats Nationaux was struck down because it was a tax masquerading as a fee. This leads to the question of whether such a tax would have been upheld had Parliament directly delegated its taxing power, instead of trying to delegate its licensing and regulatory power. Abiding by the principle behind section 53 (no taxation without representation), one would assume that such a measure would still be unconstitutional, but this is not clear from the case law. The observations of Justice Major implied otherwise in Re Eurig Estate, where he wrote that the majority of the Court's

interpretation of s. 53 does not prohibit Parliament or the legislatures from vesting any control over the details and mechanism of taxation in statutory delegates such as the Lieutenant Governor in Council. Rather, it prohibits not only the Senate, but also any other body other than the directly elected legislature, from imposing a tax on its own accord. ${ }^{67}$

This approach was subsequently supported by the Supreme Court of Canada in Ontario English Catholic Teachers' Association v. Ontario, ${ }^{68}$ where the Supreme Court of Canada upheld the delegated authority of the Minister of Finance to fix the rates of property taxes that had been imposed by statute. It remains to be seen whether this practice constitutes wholesale approval of delegating the taxation power. In the meantime, the province of Ontario has opted to run

\footnotetext{
${ }^{64}$ See Pigeon v. Recorder's Court and City of Montreal (1890), 17 S.C.R. 495; and Re Foster and Township of Raleigh (1910), 22 O.L.R. 26.

65 [2008] 3 S.C.R. 511.

${ }^{66}$ Ontario, for example, has created a number of regulatory fees under its Green Energy Act, 2009, S.O. 2009, Ch. 12, Sch. A, that may be subject to this type of criticism. See Benjamin Alarie and Finn Poschman, "Ontario's Green Energy 'Fee': The Trouble with Taxation through Regulation" (April 22, 2010) C.D. Howe Institute e-brief 98, available for download at: http://www.cdhowe.org/pdf/ebrief_98.pdf.

${ }^{67}$ Re Eurig Estate, [1998] 2 S.C.R. 565 at para. 30.

${ }^{68}$ [2001] 1 S.C.R. 470.
} 
with this broad interpretation in a number of contexts, including section 267(1) of the City of Toronto Act, 2006, which contains a clear delegation of the provincial taxing power. ${ }^{69}$

While a government may have the incentive to disguise a tax as a regulatory charge for jurisdictional or political purposes, there are also instances where legislation that is in pith and substance regulation has been masked as a tax. As with the inverse, the primary motivation behind such a scheme would be to allow for a jurisdictional end-run. Recall in the Lambe case that the province's taxation of a bank was valid as a direct tax, notwithstanding Parliament's exclusive jurisdiction to regulate banking pursuant to section 91(15) of the Constitution Act, 1867. Since the provincial legislation was in pith and substance direct taxation, any ancillary impact on banking was regarded as permissible. Compare this to Attorney-General for Alberta v. Attorney-General for Canada, ${ }^{70}$ where the JCPC held that a provincial tax on banks was in reality an effort to regulate banking within the province, and therefore ultra vires the provincial legislature. $^{71}$

\subsection{Limits on Taxation}

\subsubsection{No Internal Custom Duties}

Both the Federal and provincial governments have encountered constitutional challenges alleging that taxation or levies the might otherwise be within their jurisdiction to impose unduly inhibit free trade. In Atlantic Smoke Shops Ltd. v. Conlon, for example, the JCPC encountered the problem of whether the impugned tobacco tax, which applied to all tobacco sold in the province, including imported tobacco, violated section 121 . Following an earlier ruling of the Supreme Court of Canada in Gold Seal Ltd. v. Attorney-General of Alberta, ${ }^{72}$ the JCPC concluded that section 121 was intended to prohibit customs duties, and not to affect incidental taxes on imports as long as they were part of a universal intra-provincial direct taxation scheme.

In subsequent years, section 121 has been determined to be even narrower in its application. In Murphy v. Canadian Pacific Railway Co., [1958] S.C.R. 626, the Supreme Court of Canada considered the federal Wheat Board Act, which included a provision stating that wheat could only be traded between provinces through the Board. The Act was held to be a valid since it was in pith and substance a law that regulated the trade in grain, and therefore was consonant with to the federal trade and commerce power. Consequently, even if federal legislation had an impact upon the free flow of goods, it was not automatically invalid under section 121.

As a corollary to ss. 121 and 125, the constitution does not prohibit cross-border taxation so long as it is justified as an indirect tax under section 92(2). In Dunne v. Québec, [2007] 1 S.C.R.

\footnotetext{
${ }^{69}$ See City of Toronto Act, 2006, S.O. 2006, Ch. 11, Sch. A.

70 [1939] App.Cas. 117 (JCPC).

${ }^{71}$ Similar problems can sometimes arise at the federal level in Canada, when user fees are sometimes challenged as being taxes that did not satisfy the requirements of section 53 of the Constitution Act, 1867 and are not merely licence fees, because they are not closely tailored to the demands of a particular regulatory program.

72 (1921), 62 S.C.R. 424.
} 
853, the appellant's retirement earnings, which were derived from the profits of his former accounting firm, were taxed by the province of Québec despite his never having lived, worked, or personally earned taxable income there. However, since the firm received 20 percent of its taxable income from Québec, and that amount contributed to the appellant's retirement income, the Court held that Québec could constitutionally tax 20 percent of the appellant's retirement income as a matter of direct taxation.

\subsubsection{No Inter-Governmental Taxation}

Section 125 of the Constitution Act, 1867 prevents Parliament or the provincial legislatures from taxing each other's lands and property. It is largely focused on protecting provincial interests. This is because section 91(1A) of the Constitution Act, 1867 gives Parliament exclusive jurisdiction over "The Public Debt and Property," and therefore renders federal lands and property outside of provincial legislative grasp irrespective of section 125 . Nevertheless, the section is an unqualified prohibition that is not explicitly directed at the federal or provincial governments. Further, the terms "Lands" and "Property" have been interpreted broadly with respect to section 125, and while it is not explicit, is thought to cover direct taxation as well (such as an income tax on government revenue). Whatever is left out of section 125 is possibly protected by some other aspect of the Constitution, such as sections 102 and 126 of the Constitution Act, 1867, which restrict control over provincial and federal Consolidated Revenue Funds to their respective governments.

The most significant exception to section 125 is that while it restricts the taxation power of the two levels of government vis-à-vis one another, it does not necessarily inhibit other heads of power. In Attorney-General of British Columbia v. Attorney-General of Canada, ${ }^{73}$ the JCPC considered whether a federal customs duty and other taxes on liquor being imported by a provincial liquor board transgressed the demands of section 125 . The JCPC held that such taxes were not confined to the federal taxation power, but also implicated other heads of power, most notably section 91(2), the trade and commerce clause. Since section 125 was not meant to restrict powers other than taxation, government action executed pursuant to other heads of power were insulated from section 125 scrutiny, as long as the impugned action was not in pith and substance taxation.

While section 125 guards against taxation, this does not prohibit the recovery of payment for services rendered. In Minister of Justice v. Levis, ${ }^{74}$ the JCPC ruled that section 125 did not impact the federal government's obligation to pay a fair and reasonable charge for water supplied by a city council. However, such a fair and reasonable charge would have to be measured with respect to the cost of delivering services (as opposed to market rate) in order to prevent a province from using the guise of charges for what in reality would be indirect taxation. An example of this can be found in Societe Centrale d'Hypotheques $v$. Cite de Québec, ${ }^{75}$ where the Québec Superior Court held that a municipal charge for snow removal in

\footnotetext{
73 [1924] App.Cas. 222.

74 [1919] A.C. 505.

75 [1961] Que. K.B. 661.
} 
front of a federal building was in fact a tax, because the imposition was based on the value of the land rather than the cost of snow removal.

A more recent case combining a number of section 125 issues was Westbank First Nation $v$. British Columbia Hydro and Power Authority. ${ }^{76}$ In Westbank, the Supreme Court of Canada focused on whether a First Nations band, legislating pursuant to its taxation authority under the federal Indian Act, could tax a hydro company that was acting as an agent of the provincial Crown. In the facts of the case, the Court concluded that the fees were not enacted in the scope of the valid regulatory scheme, and that they satisfied the criteria for a tax, as established in Lawson and Re Eurig Estate, discussed above. As such, the First Nations band, as a delegate of the federal government, could not tax the respondent Hydro company, which was an agent of the provincial government. Further, while not explicit in the case, it is perhaps noteworthy that the outcome was contingent on the relative positions of the appellant and respondent under the constitutional division of powers. Had the First Nations band been acting pursuant to delegated provincial authority, or if the hydro company had been an agent of the federal Crown, the tax would have been valid, since section 125 only bars inter-, and not intra-, governmental taxation.

It is worth noting at this point that under a number of sales tax agreements (and others), Canadian governments have agreed to subject themselves to the taxes of other governments. Thus, there have been deviations from section 125 through governmental agreement. These political developments and the agreements that have emerged are discussed in the next section.

\section{Political Developments: Sub-Constitutional Federal- Provincial Arrangements}

From the time of Confederation, and more recently with the expansion of social programs in education and health care, the original allocation of taxation power-one that tilted in favour of the federal government-has not been wholly satisfactory. Pursuant to the original understanding of the Constitution Act, 1867, the provinces were given what were thought to be few major responsibilities with respect to expenditures, so it followed that the provinces required relatively modest tax means to finance these expenditures. Further, it was hoped that by restricting provincial revenues to direct (and more transparent) taxation, legislatures would be reluctant to undertake ambitious spending programs lest they face unattractive political consequences. In part, the story of Canadian jurisprudence on provincial taxation is one of finding the means to finance the provinces' increasing financial obligations. The Canadian experience has shown that education, health care, and social services are not the modest heads

of expenditure contemplated at the time of Confederation. Indeed, these heads of spending

${ }^{76}$ [1999] S.C.J. No. 38. 
accounted for more than half of consolidated Canadian federal-provincial-municipal expenditures in 2008-2009. ${ }^{77}$

The fundamental mismatch between the limited taxing power originally envisaged for provinces and the reality of their growing social expenditures has been dealt with in several ways over the years. Not only was the de facto taxing power of the provinces to some extent extended judicially as already discussed, but in addition economic and especially political changes as well as new fiscal technology have also strengthened the provincial position. First, as section 4.1 discusses, changes in economic structure and tax technology turned the income tax, the main direct tax, from the minor levy it was in the mid-19 $19^{\text {th }}$ century into the major tax of the $20^{\text {th }}$ century. Moreover, developments after World War Two ensured that the provincial share of growing income tax revenues was not only substantial but sustained by federal policy and to a considerable extent federal administration. Secondly, in recent decades major changes have taken place in the structure and operation of sales taxes at both federal and provincial levels. As section 4.2 discusses, in many ways the 'joint' federal-provincial indirect tax system that has evolved in recent years, although to some extent still in process, shares important characteristics with the longer standing 'joint' arrangements on income taxation. The outcome to date of changes in both direct and indirect taxation has been to reinforce the basic tax fact of Canadian federalism - the co-occupancy of the major tax bases by both federal and provincial governments. Thirdly, that fact has also played an important role in shaping the level, structure, and operation of the other major contributor to provincial revenues, namely, the federal transfer system, as discussed in section 4.3 with particular reference to the changing impact of natural resource revenues.

\subsection{Income Taxes}

In 1933, the first year for which we have official data, the federal government accounted for $42 \%$ of all own government revenues, provincial governments for $18 \%$, and local governments for $40 \%$ In contrast, at the end of World War II, the federal government collected $82 \%$ of all revenue. By 2000 , however, the federal share was back to $44 \%$, the provincial share was $45 \%$, and local governments had a share of only $11 \% .{ }^{78}$ Since then, the position has remained about the same. These drastic swings in revenue shares are explained almost entirely by changes in income taxes and particularly in the personal income tax.

After the depression led to crises in provincial (and local) finance, in 1937 the federal government established the Royal Commission of Dominion-Provincial Relations (commonly called the "Rowell-Sirois Commission"). When this Commission reported in 1940, after the

\footnotetext{
${ }^{77}$ See Karin Treff and Deborah Ort, Finances of the Nation, 2009 (Canadian Tax Foundation, 2010) at p. 1:2. According to the figures presented by Treff and Ort, education accounted for $16.1 \%$ of consolidated expenditures, health care accounted for $20.4 \%$ of consolidated expenditures, and social services accounted for $25.5 \%$ of consolidated expenditures.

${ }^{78}$ The source of these data and the basis for much of what follows in this section is Richard M. Bird and Francois Vaillancourt, "Changing with the Times: Success, Failure and Inertia in Canadian Federal Arrangements, 19452002" in T. N. Srinivasan, Jessica Seddon Wallack, eds., Federalism and Economic Reform: International Perspectives (New York: Cambridge University Press, 2006) at pp. 189-248.
} 
beginning of World War II, it recommended that, in order to avoid such crises in the future, not only should responsibilities, taxing powers and debt be centralized but in addition a system of equalizing grants, designed to respond to provincial fiscal needs, should be established. Although the opposition of British Columbia, Alberta and Ontario-the three provinces that would not have qualified for such grants-meant nothing was done at the time, all provincial premiers did sign on to the Wartime Tax Agreements (the so-called "tax rental" agreements) under which the provinces surrendered ("rented") all rights to impose income taxes to the federal government in exchange for fixed annual payments. ${ }^{79}$

The tax rental agreements expired in 1946. By that time, between the expansion of the economy, the increase of tax rates, and the introduction of the then new fiscal technology of withholding, the income tax had become by far the most important revenue source in Canada. The federal government would have been happy to continue its control over the tax but not all provinces agreed to maintain the Wartime Tax Agreements. After prolonged negotiation, however, seven (of the then nine) provinces signed tax rental agreements for 1947 to 1952 under an arrangement that ensured they would receive the most beneficial combination of per capita payments, Wartime Tax Agreement payments, and statutory subsidies. When it joined Canada in 1949, Newfoundland (now Newfoundland and Labrador) also signed up for this package.

However, neither of the two largest provinces, Ontario and Québec, entered into the new tax rental agreements. Instead, both provinces chose to impose their own corporate income tax $(\mathrm{CIT})$, although neither initially imposed its own personal income tax and, indeed, Ontario actually joined the agreement with respect to PIT when the agreements were renewed in 1952, on the condition that it could levy its own succession duties. However, Québec not only remained outside the agreements but also proceeded in 1954 to establish its own provincial PIT.

The next major change came in 1962. The federal government continued to collect provincial PITs in all provinces except Québec and CIT in seven provinces (all except Ontario, Québec and Alberta) at no cost to the provinces provided that the base was identical to the federal base. Moreover, the need of the provinces for more "tax room" to finance expanding social expenditures was recognized by a gradual reduction in the federal tax rate by 20 percentage points, with the reduction being offset by an equivalent increase in provincial rates. Importantly, although only Québec was free to establish its own PIT, the other provinces were now also free to determine their own rate of PIT. However, for the federal government to collect provincial taxes, those taxes still had to be imposed as a percentage of the federal tax calculated with federal exemptions, deductions and rates.

\footnotetext{
${ }^{79}$ Succession duties (inheritance taxes) were also included in these arrangements. The disappearance of death taxes as a result of inter-provincial tax competition in Canada following their abolition at the federal level is discussed in Richard M. Bird, “Canada's Vanishing Death Taxes” (1978) 27(1) Osgoode Hall Law Journal 133-145.
} 
Another important change in the 1960s was that provinces that wished to do so could further reduce the federal taxes imposed on their residents at the cost of reduced federal transfers, provided they agreed to maintain the same programs for specific health and welfare programs. Reflecting its long-standing greater desire for autonomy, Québec proceeded to "opt-out" of these programs, with the result that the federal income tax imposed in that province has long been lower than that imposed in the "rest of Canada" (ROC). Opting-out did not affect provincial revenues because transfers were reduced by an equivalent amount but it did permit the province to introduce its own preferences in such matters as the treatment of children and tax incentives for investment.

Over the next few decades, the system remained more or less the same, apart from a further reduction of federal PIT rates in the late 1970s to provide still more provincial 'tax room' to offset some of the effects of an adjustment of the federal transfer system supporting provincial health and welfare spending. The next major change came only in 1999, when the federal government for the first time allowed provinces to determine the progressivity of their own PIT rather than accepting that set by the federal tax schedule, when it agreed to collect provincial PITs at any rates imposed by the provinces so long as they used federal taxable income as a base. ${ }^{80}$ Alberta immediately took advantage of this opportunity by introducing a $10 \%$ flat tax. At the same time, Revenue Canada was reconstituted as an autonomous federal agency-the Canada Revenue Agency (CRA)-with a board consisting of both federal and provincial representatives. In 2008 Ontario turned over the collection of its CIT to the Canada Revenue Agency, with the result that at present, the CRA administers the personal income tax for all provinces except for Québec, and the corporate income tax for all provinces save for Alberta and Québec. ${ }^{81}$ In administering the CIT for eight provinces and the three territories, the tax administration and compliance functions are streamlined. For example, turning over the administration of Ontario's CIT in 2008 resulted in the compliance burden faced by Ontario businesses decreasing by an estimated $\$ 100$ million per year. ${ }^{82}$

The above (condensed) account does not really explain why so major a change in who sets the rates and collects by far the most important tax in Canada-the income tax-has taken place with so little fuss over the last few decades, especially since two aspects of the federalprovincial tax system actually moved in different directions, with the provinces achieving much more power over rates while at the same time the federal government agreed to collect their taxes at no cost to them.

No constitutional revisions were required since, as discussed earlier, both the federal government and the provinces clearly have the power to set their own tax rates and bases. All that was needed to change the system was thus agreement between governments. Moreover, given the strong party parliamentary system in Canada and (in most of this period) majority

\footnotetext{
${ }^{80}$ Actually, imposing a flat rate on an amount determined by applying a progressive rate accentuates the original progressivity. The "tax-on-base" approach had been proposed by the western provinces several years earlier.

${ }^{81}$ See the more detailed discussion in section 4.2 of the administrative agreements for sales tax administration.

${ }^{82}$ See Canada Revenue Agency, "Corporate Tax Administration for Ontario-Questions and Answers" accessed September 8, 2010; available online at: http://www.cra-arc.gc.ca/whtsnw/tms/ct-fq-eng.html
} 
governments at both federal and provincial levels, once changes were agreed they were accepted, legislated and implemented with no serious opposition or discussion. Indeed, to an astonishing extent, the entire process occurred with little public awareness or discussion - all in all, a dramatic example of the traditional importance of what has been called "executive federalism" or "federal-provincial diplomacy" in determining policy outcomes in Canada. ${ }^{83}$ To some extent, precedent may have also played a part given the dominant role of the provinces (and their dependent municipalities) before the wartime upheaval as well the perceived need for greater fiscal discipline in cost-shared programs. With history and economics on its side, and politics not strongly against it, a major shift in taxation power to the provincial level proved feasible.

Still, nothing happens in politics unless someone makes it happen. Clearly, the leadership role taken by Québec on the tax issue provided an umbrella under which others could subsequently shelter to the extent they chose to do so. A strongly 'nationalist' provincial government-the Union National-introduced the provincial PIT in 1954, urged on by an elite consensus ${ }^{84}$ that the province needed to fight against the post-war centralization tendencies of the tax-rich federal government. ${ }^{85}$ When one player in the game is strongly for something, and most other players have little or nothing to lose by going along, it is not too surprising that a positive sum outcome can emerge. $^{86}$ The provinces other than Quebec had little to lose because they gained from increased control over their revenues, and the federal government gained because as a quid pro quo for extending provincial autonomy in taxation it got more control over its expenditures.

Moreover, Canadians have turned out to be willing to accept a substantial degree of nonuniformity in fiscal matters. Provincial politicians often grumble that federal cash transfers are too low, but the differential federal PIT rates in different provinces seem to bother no one-

\footnotetext{
${ }^{83}$ See Richard Simeon, Federal-Provincial Diplomacy: The Making of Recent Policy in Canada (Toronto: University of Toronto Press, 1972).

${ }^{84}$ This elite consensus is perhaps best epitomized by the findings of the Royal Commission on Constitutional Problems, chaired by Judge Thomas Tremblay (popularly known as the "Tremblay Commission"). At least one historical account credits the Tremblay commissioners with persuading the Quebec premier to impose PIT provincially: see Paul-André Linteau, René Durocher, Jean-Claude Robert, and François Richard, Quebec Since 1930 (Toronto: James Lorimer \& Company, 1986) at p. 282.

${ }^{85}$ Over the following 50 years little changed. On May 9, 2001, the Québec government established the Commission on Fiscal Imbalance (more commonly referred to as the "Séguin Commission," after Yves Séguin, the commission's president). In its 2002 report, the Séguin Commission recommended that the federal government abandon the Canada Health and Social Transfer (CHST) system and cede still more tax room to the provinces; this recommendation was endorsed by all three major provincial parties and by almost all commentators. According to the report's summary at p. 134, "the Commission is convinced that the CHST must be eliminated and replaced with tax room freed for the provinces." See Commission on Fiscal Imbalance, A New Division of Canada's Financial Resources (Quebec, 2002); the full-text of the report is available online at: http://www.desequilibrefiscal.gouv.qc.ca/en/pdf/rapport final en.pdf

${ }^{86}$ Critical to this outcome was the underpinning provided by the equalization system discussed briefly in section 4.3 , which essentially ensured that no province would lose in an expanding economy in which everyone's fiscal boat was rising.
} 
although one reason may perhaps be because almost no one (outside of Québec) seems to realize that they exist.

On the other hand, if one looks at the situation as it is has developed in Canada in terms of the canonical model of tax assignment, Canada's present confused and confusing sharing of revenue bases is less obviously sensible - indeed it would seem conducive to reduced accountability, reduced economic efficiency, probably reduced redistributive equity, and likely increased administrative costs.

Clearly, the existence of separate Québec and federal PITs administered by different agencies implies increased compliance and administrative costs. ${ }^{87}$ However, the unified administration of the federal and provincial PITs in the ROC means that, at least until now, there have been few if any costs resulting from the developments discussed above. Matters are a bit less clearcut with respect to the other points mentioned. Traditionally, for example, it is argued that PIT should be a central tax in part because of its redistributive role. But this presumes that the only appropriate domain for redistribution is the nation as a whole, which is certainly arguable in a federal context. Similarly, although accountability would probably be greater if taxpayers had to grapple directly with a provincial tax office, the clearly distinguished provincial PIT rates arguably should make it clear enough (to those who care to look) just who is doing what to whom. Finally, even with respect to efficiency, it is by no means obvious why different rates imposed on the same base in different parts of a country in which different provinces can and do provide different packages of public services should be less efficient than a more uniform system: indeed, the contrary is arguably more likely in a federal context. In short, while there has been amazingly little research on-or concern for-any of these possible negative features of regionally differential income taxation in Canada, it seems not implausible that any such costs may be outweighed by the clear contribution that the relatively smooth transmission from highly centralized to highly decentralized income tax institutions made to the achievement and maintenance of an effective state in Canada. ${ }^{88}$

\subsection{Sales Taxes $^{89}$}

Canada first introduced a federal sales tax in 1920 in the form of a 1\% turnover tax, applied to all sales except those at retail. This tax was replaced in 1924 by a $6 \%$ tax on sales by manufacturers - the manufacturers' sales tax (MST). This tax was also unpopular, however, so

\footnotetext{
${ }^{87}$ For a discussion of these costs, and estimates of the costs if Ontario adopted its own PIT, see Brian Erard and François Vaillancourt, "The Compliance Costs of a Separate Personal Income Tax System for Ontario: Simulations for 1991," in Allan M. Maslove, ed., Taxation in a Sub-National Jurisdiction (Toronto: University of Toronto Press, 1993), 137-70, at 161.

${ }^{88}$ This argument is developed at length in Richard M. Bird and François Vaillancourt, "Fiscal Arrangements for Maintaining an Effective State in Canada" (2001) 19(2) Environment and Planning C: Government and Policy 163 187; and François Vaillancourt and Richard M. Bird, "The Interregional Incidence of Central Budgets in Federations: Some Evidence from Canada" (2007) 27(1) Public Budgeting \& Finance 1-19.

${ }^{89}$ This section is based largely on Richard M. Bird and Pierre-Pascal Gendron, "Sales Taxes in Canada: The GST-HSTQST-RST 'System,'”' (2010) 63 (3) Tax L. Rev. 517-582.
} 
its rate was gradually lowered to a level of only $1 \%$ in 1930 . The arrival of the depression and increasing fiscal deficits resulted in renewed increases in the sales tax rate to $8 \%$ in 1936, when it yielded $31 \%$ of all federal revenue. The depression also led to the introduction of the first provincial sales taxes in Canada, with retail sales taxes (RSTs) being imposed in Saskatchewan in 1937 and in Québec in 1940. Over the next 20 years, all the other provinces except Alberta introduced RSTs.

By 1990 , the MST yielded $15 \%$ of all federal taxes and RSTs accounted for $21.3 \%$ of consolidated provincial and territorial tax revenues. ${ }^{90}$ In the case of the MST, the tax base had gradually been expanded on an industry-by-industry basis to encompass more and more of the distributive sector. However, the continuous redefinition of "manufacturing" to encompass more distributive services was largely accomplished by administrative fiat, and these administrative rulings increasingly were being challenged by taxpayers, often successfully. To sustain sales tax revenues, the tax rate was gradually raised to $13.5 \%$ by 1989 . The prospect of maintaining revenue from this source simply by raising the rate on a shrinking base was not good.

It was thus not a complete surprise when the federal government finally decided in 1991 to replace the MST by a value-added tax-the Goods and Services Tax (GST). Another factor shaping this decision was increasing concern about the undesirable economic effects of the MST. Almost one-half the revenue collected from this tax came not from consumption but rather from taxes on business inputs such as the purchase of investment goods. ${ }^{91}$ Still, since hardly anyone in Canada outside government circles seemed to know the MST existed and 15\% of revenue from an invisible tax was no small gift to a hard-pressed government, the government's decision to move to the GST was both bold and controversial.

Originally, the replacement of the MST by the GST was intended to be part of a comprehensive reform of the federal income and sales taxes. Unfortunately, in the end income tax reform was introduced three years before the sales tax reform, which may be one reason why the latter reform proved so unpopular. Other arguments made against the sales tax reform were that: (i) it would be regressive; (ii) it would produce excessive revenues for the federal government; (iii) it would be too costly in terms of compliance and administrative costs; and (iv) even that it was inferior to other possible reforms (for example, reforming the existing sales or payroll taxes). ${ }^{92}$

A major political problem in introducing a federal VAT in Canada was the simple fact that all provinces except Alberta already levied retail sales taxes, at rates ranging at the time from $7 \%$

\footnotetext{
${ }^{90}$ In 1990, consolidated provincial and territorial general sales tax revenues amounted to $\$ 17.652$ billion. Total consolidated provincial and territorial tax revenues amounted to $\$ 82.754$ billion. See Statistics Canada, CANSIM Database, Table 385-0001, "Consolidated federal, provincial, territorial and local government revenue and expenditures, annual".

${ }^{91}$ Chun-Yan Kuo, Thomas McGirr and Satya Poddar, "Measuring the Non-Neutralities of Sales and Excise Taxes in Canada" (1988) 36(3) Canadian Tax Journal 655-670.

${ }^{92}$ For an assessment of these arguments, see Richard M. Bird, Where do We Go From Here? Alternatives to the GST (Toronto: KPMG Centre for Government, 1994).
} 
to $12 \%$. The GST is, of course, a very different tax from the RST in the way it operates, so it looks quite different (and appears to be more complex) to the firms that actually pay the taxes over to the government. To consumers, however, a sales tax that they have to pay when they buy anything is a sales tax, no matter what it may be called or to which government the money flows. The main economic benefit of the GST is that it frees most business inputs from tax. The other side of this coin, however, is that the fact that much of RST revenue comes from taxes on business inputs means that consumers are not aware of the full impact of that tax. With the GST, however, the full impact of the federal sales tax would be transparent to Canadians. Moreover, provincial governments understandably saw the federal government as crowding them out of "tax room" at the retail tax level and complicating their already sufficiently difficult fiscal life.

Three large provinces-Alberta, Ontario, and British Columbia-launched legal action against the federal government for exceeding its constitutional powers by introducing such a tax. Although it did not join in this suit, Québec also declared that it too considered the GST to be ultra vires the federal government. However, the Supreme Court of Canada soon ruled that the federal GST was constitutional. ${ }^{93}$ After the initial furor died down, negotiations on possible joint approaches to the VAT began with several provinces, including Québec. ${ }^{94}$

Desperate to get some province on board with the GST, the federal government finally managed to strike a rather curious deal with Québec, a province in which they faced serious political difficulties owing to the rise of the separatist movement. At the same time as the GST was introduced at the federal level, Québec simultaneously replaced its RST by a new provincial VAT, the Québec Sales Tax (QST). ${ }^{95}$ Under the federal-Québec agreement, Québec was to collect not only the QST but also the federal GST, and the federal government agreed to compensate Québec for the costs it incurred in doing so. ${ }^{96}$

The highly visible new GST, although levied only at a rate of 7\%, became a high-profile bone of contention in the federal election of 1993 and was clearly one of the factors contributing to the resounding defeat of the Conservative government. ${ }^{97}$ The winning Liberals had included a clear promise to replace the GST some more acceptable alternative. However, as often happens to winners facing serious fiscal problems they had a hard time giving up the revenue. In the end, after considerable negotiations, three small Atlantic provinces (New Brunswick, Nova Scotia, and Newfoundland and Labrador) finally agreed in 1996, in return for a substantial initial payment from the federal government, to replace their RSTs with VATs under the name of the

\footnotetext{
${ }^{93}$ Reference re Goods and Services Tax, [1992] 2 S.C.R. 445.

${ }^{94}$ Prince Edward Island, Manitoba, and Saskatchewan also entered into negotiations with the federal government, although to this day none of these provinces has entered into any arrangements with respect to sales taxation (except on certain imports of foreign goods).

95 Québec's constitutional authority to impose such a tax was recognized by the Supreme Court of Canada in Reference re Québec Sales Tax, [1994] 2 S.C.R. 715.

${ }^{96}$ Québec receives a negotiated annual fee for administering the GST in the province.

${ }^{97}$ A useful review of GST politics at this time is provided by Richard Eccleston, Taxing Reforms: The Politics of the Consumption Tax in Japan, the United States, Canada and Australia (Cheltenham, UK: Edward Elgar, 2007).
} 
Harmonized Sales Tax (the HST). The federal government declared victory,, stressing that, as initially promised in the election campaign, it had indeed replaced the GST--by the GST/HST. Essentially, the GST remained exactly as it was-a federal credit-invoice VAT. In addition, however, three provinces had now replaced their RSTs by provincial VATs levied at the uniform rate of $8 \% .{ }^{98}$ Unlike the QST, however, the new provincial VATs were levied on the same base as the federal GST. Moreover, the federal government collected both federal and provincial components of the HST.

In 1991, the federal government probably accepted the rather peculiar agreement with Québec owing not only to its rather strained (especially at that time) relations with the province but also in an effort to induce other recalcitrant provinces to hop on the VAT bandwagon. From the beginning, however, the HST path of a combined federal and provincial tax, administered federally, was undoubtedly its preferred approach. Despite the success of the HST in the eastern provinces, ${ }^{99}$ however, it was not until 2010 that any other province proved willing to accept the restrictions of the HST agreement. ${ }^{100}$ Nor had any province chosen to take sales tax reform in its own hands in the more independent Québec-style, that is, by adopting a provincial VAT that is less closely tied to the federal GST system.

It was thus somewhat of a surprise in March 2009 when Canada's largest province, Ontario, announced that it intended to replace its existing 8\% RST by an 8\% VAT imposed on essentially the same base as the federal GST. In effect, Ontario joined the HST system, with the new tax coming into effect in July 2010. There appear to have been at least four reasons for the provincial decision to follow this path. First, the province appears to have been persuaded by earlier empirical studies of the HST experience that the shift in sales taxation would benefit it economically, perhaps quite substantially. Second, for (unclear) reasons of its own, the federal government gave Ontario what looks to be a very good deal. Not only will Ontario receive a special additional federal payment of $\$ 4.3$ billion ( $\$ 3$ billion on introduction of the tax, and $\$ 1.3$ billion if it is still in force one year later) but the federal government will cover all the costs of administering the tax. ${ }^{101}$ Moreover, the federal government has not only accepted more base deviations from Ontario (for example, zero-rating for children's clothing and other items) than in any existing HST province but also (for five years, followed by a three-year phase-out)

\footnotetext{
${ }^{98}$ Why the federal government insisted that all HST provinces apply the same rate is unclear. There is no technical necessity for such uniformity.

${ }^{99}$ On this, see Michael Smart, "Lessons in Harmony: What Experience in the Atlantic Provinces Shows About the Benefits of a Harmonized Sales Tax" (July 2007) CD Howe Institute Commentary, No. 253, available online at: http://www.cdhowe.org/pdf/commentary 253.pdf; and Michael Smart and Richard M. Bird, "The Economic Incidence of Replacing a Retail Sales Tax with a Value-Added Tax: Evidence from Canadian Experience" (2009) 35(1) Canadian Public Policy 85-97 and Michael Smart and Richard M. Bird, "The Impact on Investment of Replacing a Retail Sales Tax by a Value-Added Tax: Evidence from Canadian Experience," National Tax Journal, 62 (4): 591-609.. ${ }^{100}$ An official report in the province of Saskatchewan had recommended that, provided it received adequate compensation, the province should sign up for the HST, although at a lower rate (5\%); see Saskatchewan Business Tax Review Committee, Final Report of the Saskatchewan Business Tax Review Committee (Regina: 2005). Nothing came of this proposal.

101 See Comprehensive Integrated Tax Coordination Agreement between the Government of Canada and the Government of Ontario (2009), available online at: http://www.fin.gov.on.ca/en/publications/2009/citca.pdf
} 
Ontario is allowed to impose restrictions on certain input credits, provided they are similar to those already in place in the QST. Third, the federal government had earlier in effect opened up some 'tax room' for the provinces by reducing its GST rate from $7 \%$ to $5 \%$ in $2006 .{ }^{102}$ Fourth, by imposing the same $8 \%$ rate as under its previous RST, the province increased its revenues owing to the broader base of the new HST. ${ }^{103}$

Ontario thus gains revenue and a (probable) economic boost without losing any significant policy autonomy. More money, less administrative outlay, better economic outcomes; what is not to like? Of course, the politics of the tax substitution are by no means as simple as this may suggest but there is probably enough money attached to this reform to allow the province to buy its way out of any tough spots.

The rate reduction and consequent revenue loss was the stated rationale for the compensatory payments to the original HST provinces in 1996. Although no one has officially stated any rationale for the payment to Ontario, which has probably increased rather than reduced its sales tax take by the reform, two possible rationales might be suggested. First, although no official source is likely to articulate this point explicitly given prevailing regional sensitivities, if the boost to investment and growth following the RST-HST substitution benefits Ontario-by far the largest province in terms of both population and economic activity in the country-then it presumably also benefits Canada. ${ }^{104}$ Second, in the current economic crisis, giving a major boost to private investment through this sales tax reform may be more useful than such other federal 'stimulus' outlays as subsidies to this or that currently fashionable activity or general public infrastructure funding.

Similar reasons appear to have been at work in British Columbia, which also replaced its provincial RST by a 7\% provincial HST in July 2010. Like Ontario, British Columbia will receive a lump sum payment (\$1.6 billion) from the federal government, free federal administration, considerable freedom to design its own consumer rebates, as well as limited authority to restrict ITCs, so again from a provincial perspective the deal seems like a winner. However, the political reaction has been much more adverse in that province as the unpopularity of its current government has been exacerbated by the perception that in introducing the HST the government broke a commitment made prior to the most recent election.

One reason for adverse public reaction both to the federal GST in 1991 and the later provincial HSTs is that in Canada, unlike any other country with a VAT, the tax is almost always quoted

\footnotetext{
102 This point is emphasized in Michael Smart and Richard M. Bird, "The GST Cut and Fiscal Imbalance," in Charles Beach, Michael Smart, and Thomas A. Wilson, eds., The 2006 Federal Budget: Rethinking Fiscal Priorities (Montreal: McGill-Queen's University Press, 2007), 73-100.

${ }^{103}$ See Peter Dungan, Jack Mintz, Finn Poschmann, and Thomas Wilson, "Growth-Oriented Sales Tax Reform for Ontario: Replacing the Retail Sales Tax with a 7.5 Percent Value-Added Tax" (September 2008) CD Howe Institute Commentary No. 273, available online at: http://www.cdhowe.org/pdf/Commentary 273.pdf.

104 The economic benefits of substituting an HST for an RST are detailed in Smart and Bird, "The Impact on Investment of Replacing a Retail Sales Tax by a Value-Added Tax: Evidence from Canadian Experience," National Tax Journal, 62 (4): 591-609.
} 
separately on all transactions, including those to final consumers. The view expressed at the time of the GST's introduction by the federal Department of Finance was that a visible tax would be superior for political reasons to tax-inclusive pricing, which had been thought to be a drawback to the MST system. ${ }^{105}$ Provincially, one might argue that RST must, for constitutional reasons, be expressed as a tax on purchasers (since provinces are restricted to levying only "direct" taxes), and separate quotation of the RST (tax-exclusive pricing) reflects this legal requirement. The federal GST is under no such constraint, however, and in fact the law provides for either tax-inclusive or tax-exclusive pricing. ${ }^{106}$ The original intention in 1991 was to shift over time to tax-inclusive pricing (as in the EU VAT, with GST shown separately on the receipt or invoice but included in the posted price) rather than tax-exclusive pricing (as in the RST), and this was still the aim at the time of the introduction of the HST in 1996. However, because of extensive public criticism in the end vendors were again given the option of tax-exclusive pricing. ${ }^{107}$ Tax-exclusive pricing continues to prevail in Canada with the result that sales taxes, both federal and provincial (whether RSTs, HST, or QST) continue to be highly visible. ${ }^{108}$

Apart from the general question of tax harmonization, federal-provincial issues also affected some important areas with respect to the design of the GST. Since, as discussed earlier, federal and provincial governments cannot tax each other, so the federal GST could not be applied to sales to provincial governments. However, the governments of the HST provinces, like the federal government, have agreed to pay GST/HST on their taxable purchases. ${ }^{109}$ Sales to other provinces are not taxable if properly certified; since suppliers are entitled to claim ITCs on all supplies made to provincial or territorial governments, whether or not GST/HST is collected, in effect such sales are zero-rated. These rules do not apply to provincial public sector enterprises (Crown corporations) such as the large electricity suppliers, so these companies are both responsible for collecting the tax on their sales and can claim refunds of taxes imposed on their

\footnotetext{
${ }^{105}$ See Department of Finance, Goods and Services Tax: Technical Paper (Ottawa: Department of Finance, August 8 , 1989). See also the discussion in David M. Sherman, “Tax-Included Pricing for HST: Are We There Yet?" (2009) 57(4) Canadian Tax Journal 836-856.

${ }^{106}$ See Excise Tax Act, R.S.C., Ch. E-15, Sch. V, 223(1).

107 David Murrell \& Weiqui Yu, "The Effect of the Harmonized Sales Tax on Consumer Prices in Atlantic Canada" (2000) 26 Canadian Public Policy 451 at p. 453.

${ }^{108}$ For a recent discussion of the economics and politics of tax-inclusive pricing, arguing that tax-inclusive pricing is undesirable, see Richard M. Bird, "Visibility and Accountability: Is Tax-Inclusive Pricing a Good Thing?" (2010) 58(1) Canadian Tax Journal 63-76.

${ }^{109}$ This is a feature of all the HST agreements. See, for example, the recently revised agreement with Nova Scotia, Comprehensive Integrated Tax Coordination Agreement between the Government of Canada and the Government of Nova Scotia, Article 51, available at http://www.gov.ns.ca/finance/site-finance/media/finance/taxation/CanadaNS CITCA 2010-04-01.pdf. Interestingly, both the province of Prince Edward Island (which levies its own RST) and the territory of Nunavut (which has no sales tax) have also agreed to pay tax on taxable purchases: see http://www.cra-arc.gc.ca/tx/bsnss/tpcs/gst-tps/thr/gvt/prvncl-eng.html. Such agreements are reciprocal, that is, the federal government would also agree to pay RST on its purchases if the province or territory had such a tax (Nunavut does not). From the perspective of vendors, it is obviously simpler to be able to apply tax than to deal with exemptions, so it is not surprising that the federal government attempts to negotiate such arrangements through the reciprocal tax agreements related to GST that it has with all provinces. These agreements are in any case needed to deal with a variety of issues, for example whether hospitals in particular provinces are considered part of the provincial public sector or not.
} 
inputs. In principle, the important public sector institutions included in the so-called MASH (municipalities, academic, schools, and hospitals) sector, as agents of the provinces, were exempt from charging federal GST on sales (unless they sold taxable goods). On the other hand, unlike the provincial governments these institutions were subject to tax on business inputs. The federal government decided to provide a partial refund of taxes on inputs purchased by the MASH sector in order to keep these institutions in more or less the same relative position as they had previously been under the manufacturers' sales tax (which was embodied in the prices of their inputs). ${ }^{110}$ Although the refunds varied by type of provincial body, on average they amounted to roughly two-thirds of input taxes paid by the sector. ${ }^{111}$

Subnational governments have the choice of whether or not to impose their own VATs. ${ }^{112}$ As of July 2010, four subnational jurisdictions impose no sales taxes: Alberta, Northwest Territories, Nunavut, and Yukon. Three provinces (New Brunswick, Ontario, and Newfoundland and Labrador) impose the HST at $8 \%$. One province (British Columbia) imposes the HST at a rate of $7 \%$. One province, Nova Scotia, imposes HST at a rate of $10 \%$ on the same base as the federal tax, which is administered along with the GST by the federal tax administration. As explained above, Québec levies an independent VAT, the QST, which includes the federal GST in its base and is administered, together with the federal GST, by the provincial tax administration. Finally, three provinces (Saskatchewan, Manitoba, and Prince Edward Island) continue to impose separate RSTs administered provincially, with one of these provinces (Prince Edward Island) including the GST in its tax base.

Although all the HST provinces (and Québec) essentially tax the same base as the federal GST, in every case there are important differences in exactly how the tax works. Even in the 'traditional' HST provinces, for example, all-like Québec, but unlike the federal GST-zero-rate books. All HST provinces follow the GST in providing a $50 \%$ rebate for charity, ${ }^{113}$ but only Nova Scotia follows the federal model of similar rebates to the MASH sector, and even that province did not follow the 2004 federal increase in the rebate to municipalities. ${ }^{114}$ Newfoundland gives no rebate to municipalities. Only Nova Scotia (like Québec) gives any rebates at all on new

\footnotetext{
110 This system is discussed in Pierre-Pascal Gendron, "Value Added Tax Treatment of Public Sector Bodies and Non-Profit Organizations: A Developing Country Perspective" (2005) 59(12) Bulletin for International Fiscal Documentation 514-526.

${ }^{111}$ This is simply the (approximate) average of the percentage rebates allowed for the various components of the MASH sector. Given the huge and varied collection of VAT registrants in Canada lumped together as "nonprofits," their $50 \%$ rebate seems more likely to be a compromise between $0 \%$ and $100 \%$ than based on any careful study. Interestingly, the same (arbitrary) rate applied in 2009 in all the provincial VATs, although most apply other rebates in other sectors. The appeal of a good compromise untested by any factual basis should not be underestimated. 112 U.S. states could also do so, as argued in Richard M. Bird, "Is a State VAT the Answer? What's the Question?" State Tax Notes, 45 (no. 13), September 24, 2007): 809-25. However, as yet the only state VAT in the United States appears to be a rather peculiar 'apportioned VAT' in Michigan: see Michael J. Mclntyre, and Richard Pomp (2009) “Michigan's New Apportioned Value Added Tax," State Tax Notes, 51, no. 9 (March 2): 673-87.

${ }^{113}$ See Department of Finance, Harmonized Sales Tax: Technical Paper (1996). This technical paper was issued jointly by the governments of Canada, Nova Scotia, New Brunswick, and Newfoundland and Labrador.

114 See Canada Revenue Agency, GST/HST Information for Municipalities (2005) available at http://www.craarc.gc.ca/E/pub/gp/rc4049/README.html.
} 
housing and, again like Québec, it does so in a different way to the federal GST. In addition, each province has its own specific rebate provisions. For example, Newfoundland and Labrador effectively zero-rates residential building materials used in the sparsely-settled Labrador region; ${ }^{115}$ Nova Scotia similarly zero-rates material used for "heritage properties" and fire departments, ${ }^{116}$ and New Brunswick does so for certain research and development activities at universities. ${ }^{117}$ Only Newfoundland offers a low-income credit (like the federal GST credit). ${ }^{118}$ This provision, like the book rebates, is provincially legislated but federally administered. ${ }^{119}$ However, other provincially legislated rebates - for home heating, volunteer fire departments, vehicles and computers for the disabled, and the like--are administered directly by the provinces.

Of course, the less "coordination" there is between sales taxes in subnational jurisdictions and any federal tax (or for that matter between different subnational sales taxes) the higher the administrative costs for governments and the higher the compliance costs for businesses. Nothing is free, however. Provincial governments may choose to impose such costs on their businesses and residents in order to retain some desired degree of fiscal autonomy. Indeed, such autonomy in some instances may even provide an external benefit in the form of innovations by independent decision-makers to improve the efficiency of sales taxes. In Canada, one such example might be Québec's different--and in some ways preferable-treatment of financial services. ${ }^{120}$

If a province decides to impose a VAT, it is a quite separate decision whether it should be administered jointly or separately with the federal VAT and by whom. In Canada, all VATs are administered by a single agency: in Quebec, that agency is provincial; in the rest of the country it is the CRA. The argument for a single administration is strong on administrative and

\footnotetext{
${ }^{115}$ See Tax Agreement Regulations (Tax Agreement Act) N.L.R. 31/97 (Nfld.). To clarify a possible confusion, 'zerorate' is the accepted terminology for allowing full input tax credits (ITCs) for a good or service that is not subject to any positive VAT rate on final sale. In Canada, such zero-rating is accomplished in three different ways. First, a province can 'zero-rate' something from its portion of the HST by 'rebating' it (i.e., not collecting it) at the point of sale. In the case of the MASH sector, however, which for the most part does not in any case 'sell' its output, the same objective-refunding VAT on inputs-is accomplished by actual rebates (payments from government budgets). In this instance, 'rebate' is the instrument used to achieve 'zero-rating'. Of course, to confuse matters, there are also many other types of GST 'rebates' such as for new primary residences There is also some explicit 'zero-rating' such as for basic groceries.

116 Sales Tax Act Regulations (Revenue Act) N.S. Reg. 33/97 (N.S.), available at http://www.canlii.org/en/ns/laws/regu/ns-reg-33-97/latest/ns-reg-33-97.html.

117 General Regulation (Harmonized Sales Tax Act) N.B. Reg. 97/28 (N.B.), available at
http://www.canlii.org/en/nb/laws/regu/nb-reg-97-28/latest/nb-reg-97-28.html.

${ }_{118}$ Income Tax Act, Nfld.S., c. I 1.1 § 34 (2009), available at http://www.canlii.org/en/nl/laws/stat/snl-2000-c-i1.1/latest/snl-2000-c-i-1.1.html\#34.

$\frac{1.19}{119}$ it is thus similar to the federal GST credit against PIT; provincial credits for provincial retail sales taxes may also be administered by CRA as part of administering the provincial income tax on behalf of the province, as in the case of Ontario.

${ }^{120}$ See Pierre-Pascal Gendron "VAT Treatment of Financial Services: Assessment and Policy Proposal for Developing Countries," Bulletin for International Taxation, 62 (11, November 2008) , 494-97
} 
compliance cost grounds, but which path is chosen in terms of administration is largely a political choice with no important economic consequences.

Achieving a "coordinated" two-level sales tax structure requires considerable effort. First, basic political agreement has to be secured between governments with different interests. Second, an appropriate legal framework to implement that agreement has to be worked out. Third, an appropriate administrative structure must be agreed on. Fourth, to make the system work over time, appropriate oversight and cooperation systems between governments need to be developed and put into place. The result of about a decade of discussion of all these matters in Canada was the two quite different ways of coordinating some provincial-federal sales tax systems described above. Another decade led two more provinces, Ontario and British Columbia, to decide to enter the HST system under, more or less, their own terms. Even, however, after these systems have been working, successfully, for over a decade, four of Canada's ten provinces have signed on to neither of them. That they have not done so has arguably harmed the residents of those provinces with RSTs by perpetuating existing distortions arising from tax cascading. It has not, however, hampered the functioning of either the federal GST or the varied provincial equivalents - the QST and the HST. As in the income tax area, Canada has, over time, succeeded in developing a complex but workable way in which two independent levels of government may impose separate taxes on essentially the same tax base without either imposing unreasonable costs on taxpayers or unduly constraining the policy autonomy of each level of government.

\subsection{Transfers and Natural Resource Revenues}

Who gets the revenue from natural resources has always been contentious in Canada despite the clear provincial constitutional jurisdiction in this area. One reason is selective historical memory. For example, the production of oil and gas in Canada is concentrated in the province of Alberta. This concentration produced considerable strains on Canadian fiscal federalism in the era of high oil prices from 1973 to 1985 . As late as 1974, Alberta, despite its above average per capita GDP level, had been a recipient of equalization transfers. With the surge in oil prices, however, per capita GDP in Alberta quickly rose to unprecedented heights. Since natural resources are, for the most part, owned by the provincial governments in Canada, provincial policy has traditionally controlled access to, the removal of, and the price of natural resources. ${ }^{121}$ Understandably, therefore, the Alberta government attempted to capture the vastly increased resource rents through its royalty policy.

Unfortunately, from the federal point of view this attempt had a potentially disastrous effect. Since the equalization system then in place was largely driven by changes in the level of provincial revenues, increasing provincial resource revenues raised the level of required

\footnotetext{
${ }^{121}$ One of the more interesting features of federalism is the selective nature of regional historical memory. Few policymakers in Alberta seem to have forgotten that when the province was created from federal lands in 1905, the federal government retained the ownership of resources until 1930 even though it had turned over the same ownership to Ontario and Québec when they were expanded with similar federal lands in 1912. On the other hand, the collective provincial memory of the many years during which Alberta was a "recipient" province of equalization transfers seems to be nonexistent.
} 
equalization payments. But these payments came entirely from federal revenues, and, because provincial royalties are a deduction for purposes of calculating corporate income taxes, federal revenues were actually lower, not higher, when provincial oil royalties increased. Confronted with these unpalatable facts, coupled with its desire to shield the oil-consuming-and politically dominant-central provinces (Ontario and Québec) from some of the effects of the world price rise both by setting a lower Canadian price (which would benefit Ontario) and by using the revenue from a tax on oil exports to subsidize oil imports (thus benefiting Québec and Atlantic Canada), the federal government proposed what was called a National Energy Policy (NEP) to share the resource rent from taxation. Although the crisis vanished with the fall of oil prices before the NEP really came into effect, the resulting political bitterness has lingered in Alberta to this day, and some of the other ameliorative policies undertaken at the time-such as the limitation of the deduction of royalties for federal tax purposes and the redesign of the equalization formula to, in effect, eliminate Alberta's revenues from the base-also remain.

An earlier national oil policy-before the NEP-had similarly aroused regional concerns, although in a very different way. That policy divided the Canadian oil market into two by a line (the Borden line) which ran close to the Québec border, with markets to the east being served by imported oil and markets to the west by (higher-priced) Canadian oil. One might have expected this policy to be resented by the Ontario industrial heartland, which was thus (in effect) forced to subsidize western oil production. In fact, however, the main effect of this policy appears to have been resentment by some politicians in Québec of the resulting growth of a petrochemical complex in southwestern Ontario that rivalled the one earlier established in Montréal. ${ }^{122}$ In a federal country in which resources are regionally based and both federal and provincial governments are able to affect who gets how much, conflicts about resources never seem to end.

For the most part, however, apart from the constitutional change discussed in section 2.5, policy responses have occurred more with respect to transfers than in the tax field. In particular, the extended debate over equalization in recent years has largely been driven by resource-based concerns. The introduction of special arrangements for the treatment of revenues accruing from offshore oil to the provinces of Nova Scotia and, later, Newfoundland and Labrador, in effect largely protecting those provinces from reductions in equalization as a result of these new revenues was one factor leading to a major revision of the equalization arrangements in 2004 and then to a subsequent expert panel report that focused to considerable extent on the appropriate treatment of resource revenues in calculating equalization payments. ${ }^{123}$ Because of this report, yet another major revision of the equalization system was announced in 2007. Although under the current system, the existing offshore arrangements, which basically exclude oil revenues from the calculation for Newfoundland and Labrador remain in effect until they expire (in 2011-12), the immediate

\footnotetext{
${ }^{122}$ Mireille Éthier, "Regional Grievances: The Quebec Case” in Kenneth Norrie, ed., Disparities and Interregional Adjustment (Toronto: University of Toronto Press, 1986).

${ }^{123}$ For a useful summary of this report and the preceding and subsequent revisions in the equalization system, see Karin Treff and Deborah Ott, Finances of the Nation 2009 (Toronto: Canadian Tax Foundation, 2010), at 7:2 to 7:7.
} 
reaction of the new government in the province was strongly adverse - to the point of ceasing to taking down the national flag from provincial buildings. Subsequently, however, the level of political heat diminished and at present the issue of resource revenues and equalization, although not forgotten, is no longer in the headlines.

More generally, taxation arrangements in a fiscal federation are inextricably related to intergovernmental fiscal transfers. ${ }^{124}$ In federations like Canada, the major tax bases are largely co-occupied in the sense that each level of government may make independent decisions about the tax, particularly with respect to rates. In Canada, the only major tax bases not shared by both levels are the resource and property tax bases that are assigned exclusively to the provinces, and as already discussed in the case of resources, even these bases are to some extent 'co-dependent' with federal tax treatment of provincial (and local) taxes on property and resources. With respect to the PIT, although the tax is collected by the federal government (outside Québec) and imposed on the same base as the federal income tax, provinces both set the tax rate and receive the revenues attributable to their jurisdiction. In effect, the provinces have simply contracted for the services of the central government as a collection agent. With respect to sales taxes, in Québec the federal GST is collected by the provincial government along with its own QST (imposed on more or less the same base) and the federal proceeds are remitted to the federal government; each government independently sets its own tax rate. In contrast, in the five HST provinces, a provincial VAT is imposed at a rate set by the province on the same base as the federal VAT, both VATs are collected by the federal government and the proceeds of the provincial tax are remitted to the provinces in question. ${ }^{125}$

It has long been recognized that overlapping tax bases of federal and subnational governments can give rise to externalities analogous to those resulting from horizontal tax competition. Such interactions are obviously strongest when tax bases are shared as in Canada, because tax increases by one level of government induce private sector avoidance activities that will, all else the same, reduce revenues earned by the other level of government. Ignoring federal accountability problems a benevolent federal government could (and perhaps should) internalize this impact: after all, federal and provincial taxpayers are ultimately the same people. $^{126}$ For provincial governments, however, the case is not so clear: since federal revenues lost due to provincial tax increases will tend to be borne by residents of other provinces, the resulting negative fiscal externality is likely to result in excessive taxation.

\footnotetext{
${ }^{124}$ Much of the remainder of this section is based on Richard M. Bird and Michael Smart (2010), "Assigning State Taxes in a Federal Country: The Case of Australia," in Melbourne Institute, Australia's Future Tax and Transfer Policy Conference (Melbourne: Melbourne Institute of Applied Economic and Social Research), pp. 72-94.

${ }^{125}$ Revenues are distributed by a formula intended to allocate revenues to the province in which final consumption takes place. The details of this revenue allocation system are set out in Bird and Gendron, "Sales Taxes in Canada: The GST-HST-QST-RST 'System,'”' (2010) 63 (3) Tax L. Rev. 517-582.

${ }^{126}$ The "perhaps" in the text sentence is because the "should" in the sentence depends on the arguable prior assumption that the federal government has the overall responsibility for fiscal redistribution in the country as a whole and hence should override differing regional preferences.
} 
While the theoretical argument is relatively straightforward, its relevance to policy is less so. For one thing, as just mentioned a federal government that recognizes the problem should be able to design federal tax and transfer policies to achieve an efficient outcome-although, as pointed out by Boadway and Keen, ${ }^{127}$ this may involve reducing federal tax rates to such an extent that the vertical gap is reversed, with transfers running from the states to the federal government. Another thing is that the tendency to excessive federal taxation due to cooccupancy must be balanced against the tendency to under-tax arising from horizontal tax competition between provinces. ${ }^{128}$ The net impact of federalism on the overall level of taxation is thus an empirical matter and it is impossible at present to say whether the effects are important in practice. ${ }^{129}$

Whatever the overall importance of vertical externalities, as Keen emphasizes, ${ }^{130}$ the effects are likely to be largest when, as in Canada, the relative shares of provinces and federal government in total government spending are nearly equal so that the bilateral externalities are largest. For example, with rising provincial social expenditures vertical externalities resulting from co-occupied tax bases are a much more important concern in Canada than in Australia, where states are substantially less important and where co-occupancy is unknown. However, while the potential for excessive taxation as a result of co-occupancy is clear in Canada, its importance has not been conclusively demonstrated. Moreover, as mentioned above, given enough instruments the federal government acting in the national interest can always offset any inefficiency in provincial taxation that might result from co-occupancy either through negotiated arrangements under which tax room is shared between orders of government (as has frequently been done in Canada) or through designing transfers that take into account the likely fiscal reactions of the provinces. Indeed, even federal transfer programs designed for entirely different purposes may serve to align the incentives of federal and provincial governments and hence reduce the problems of co-occupancy-or at least they may do so to internalize to some extent the impact of increased transfers on federal taxes and hence on provincial tax room. ${ }^{131}$

In the standard view of fiscal federalism, the central government may commit to an appropriate level of federal transfers simply by computing the appropriate level of vertical fiscal gap - the difference between desired provincial expenditures and provincial own-revenues - and paying it to provinces as a block grant. However, this approach cannot work in a system in which

\footnotetext{
${ }^{127}$ Boadway, R. and J-F.Tremblay (2006) "A Theory of Vertical Fiscal Imbalance," Working Paper 1072, Department of Economics, Queen's University, Kingston, Canada.

${ }^{128}$ Keen, M. and C. Kotsogiannis, “Does Federalism lead to Excessively High Taxes?” (2002) 92(1) American Economic Review 363-370.

${ }^{129}$ In one interesting recent contribution, however, Bruelhart and Jametti argue that in the case of local taxation in Switzerland, indirect evidence suggests that the vertical externality raises tax rates sufficiently to more than offset the horizontal externality pushing tax rate down. See Bruelhart, M. and M. Jametti, "Vertical versus Horizontal Externalities: An Empirical Test" (2006) 90 Journal of Public Economics 2027-2062.

${ }^{130}$ Keen, M., "Vertical Fiscal Externalities in the Theory of Fiscal Federalism" (1998) 45 IMF Staff Papers 454-85.

${ }^{131}$ On this argument, see Caplan, Arthur J. \& Cornes, Richard C. \& Silva, Emilson C. D., "Pure public goods and income redistribution in a federation with decentralized leadership and imperfect labor mobility" (2000) 77(2) Journal of Public Economics 265-284.
} 
major tax bases are shared between federal and provincial governments. Indeed, when tax bases are shared, it is difficult to determine the appropriate level of intergovernmental transfers on any principled basis. Should federal personal income taxes rise to finance increased health care expenditures, or should provinces with access to the income tax base impose their own increased rates? In the absence of important inter-provincial spillovers in taxation or spending, the economic consequences of the two options are little different. When federal and provincial governments have access to essentially the same tax bases, there is no apparent reason why provinces should not raise their own tax rates to finance increased spending rather than relying on the federal government to do so.

Vertical fiscal imbalance when there is base co-occupancy is thus fundamentally a political concept, not an economic one. ${ }^{132}$ Each level of government has its own rhetoric on the issuerhetoric that usually receives very little credence from the other level. Indeed, the evidence on the evolution of federal transfers in Canada in recent years suggests that even the federal government does not even believe its own rhetoric since transfers have increased substantially for no obvious reason except in response to provincial demands. Since the appropriate vertical gap is essentially indeterminate, it is not surprising that Canadian governments have had a difficult time in recent years determining the appropriate level of federal transfers, with resultant muddying effects on accountability. ${ }^{133}$ Vertical overlap of taxes is of course also a source of potential waste, inefficiency, and citizen irritation. To the extent it reinforces the idea that all responsibilities are ultimately federal, co-occupancy of tax bases may thus exacerbate such problems of soft budget constraints as undesirable expansions of subnational spending. On the other hand, it might be argued that vertical fiscal competition between governments may equally well work in the opposite direction and end up improving both accountability and the efficiency of government spending and taxation at all levels. ${ }^{134}$ As Canadian experience shows, with appropriate flexibility in both the tax and transfer areas, one can perhaps not only live with some degree of base co-occupancy but even benefit from it to some extent; however, it is neither an easy nor a costless process to do so.

Another problem with any transfer system is that it may create a disincentive for state governments to raise their own revenues. To avoid such problems, as stipulated in section 36(2) of the constitution, federal equalization transfers are to provide each provincial government with sufficient funds (own-source revenues plus transfers) to deliver a reasonable level of services provided it imposes a reasonable level of taxation-where the definition of 'reasonable', although it has altered to some extent over time, basically comes close to the

\footnotetext{
${ }^{132}$ For a different, but related, treatment of this issue, see Richard M. Bird, "Fiscal Flows, Fiscal Balance and Fiscal Sustainability," pp. 81-97 in Richard M. Bird and François Vaillancourt, eds., Perspectives on Fiscal Federalism. WBI Learning Resources Series (Washington, DC: World Bank, 2006).

${ }^{133}$ For a review of the most recent developments in Canada, see Smart, M. (2009) "The Evolution of Federal Transfers since the O'Brien Report," Paper presented at Conference on the 2009 federal Budget: Challenge, Response, and Retrospect, John Deutsch Institute, Queen's University, Kingston, Canada.

${ }^{134}$ For a recent theoretical argument that, in certain circumstances, interregional redistribution can 'cure' the soft budget syndrome, see e.g. Akai, N. and E. Silva (2009) “Interregional Redistribution as a Cure for the Soft Budget Syndrome in Federations" (2009) 16(1) International Tax and Public Finance 43-58.
} 
average level of services provided by provinces as a whole. An equalization grant is in effect a system of revenue sharing. In idealized form, such a system sets the (per capita) transfer to each government equal to the difference between its tax capacity and the average capacity of all provinces, multiplied by some standard tax rate, usually equal to the average of all provincial tax rates. Tax capacity is measured by the observed per capita tax base of each jurisdiction. Thus the program aims to equalize differences in tax revenue but implements transfers through an indirect formula, based on differences in observed tax bases.

Since capacity equalization in effect pays provinces (out of federal revenues) for the deficiency in provincial tax bases, multiplied by national average rates, any increase in the tax base of a receiving province is taxed back through the formula. If the province levies the national average rate on its own base, the effective rate of tax-back as a percentage of revenues is exactly 100 per cent. If the rate is below the national average, however, then tax-back may exceed 100 per cent. In this case, the equalization formula acts to deter governments in receiving provinces from attracting new investment or developing new revenue sources: instead, it may create a cycle of dependency' for receiving governments. In fact, the adverse incentive effects of equalization can be even more extensive and potentially harmful than this because there is a financial incentive for receiving provinces to set local tax rates higher than desirable from a national point of view. ${ }^{135}$ This adverse incentive occurs even when a province is small and has a small share of national revenues for a base. The reason is that measured tax bases generally decrease as tax rates rise-for instance as higher taxes are capitalized in property values and as economic activity moves to other jurisdictions or to more lightly taxed transactions. Consequently, although governments that raise their tax rates will see their tax bases depressed, their transfers will increase. This effect is clearest when considering a receiving province with a tax rate equal to the national average for the base: At this point, as Smart shows, ${ }^{136}$ further increases in the rate will generate increases in transfers that exactly compensate for the dollar value of deadweight' economic losses resulting from higher tax rates. In short, equalization transfers intended to offset horizontal inequities tend to drive tax rates in receiving provinces above the national average. In addition, when equalization is based on a 'representative tax system' approach (as in Canada) it also creates incentives to change the tax mix because provinces can increase the transfers they receive by relying more on tax bases that are very elastic or have high national average tax rates, and less on other bases.

An emerging empirical literature provides some evidence of the tax-raising effects of capacity equalization. Boadway and Hayashi ${ }^{137}$ report that Canadian provinces that receive equalization are more inclined than others to raise business tax rates when the national average rate goes up: this is consistent with the notion that equalization insulates receiving provinces from some

\footnotetext{
135 Ibid.

${ }^{136}$ Michael Smart, "Taxation and Deadweight Loss in a System of Intergovernmental Transfers" (1998) 31 Canadian Journal of Economics 189-206.

${ }^{137}$ Boadway, R. and M. Hayashi, "An Evaluation of the Stabilization Properties of Equalization in Canada" (2004) 30 Canadian Public Policy 91-109.
} 
of the pressures of tax competition and hence permits them to set higher rates. Smart finds related tax-raising effects for other tax bases in Canada. ${ }^{138}$

The details of how federal-state equalization transfers work may thus affect both the level and the structure of provincial taxes and lead to more or less economically desirable outcomes. Decentralization with equalization is perhaps less likely to lead to the much discussed 'race to the bottom' than to a reduction in tax competition to the extent equalization transfers provide support for a provincial tax 'cartel.' ${ }^{139}$ Although neither the theoretical nor the empirical literature is yet conclusive, the main conclusion that emerges convincingly from the discussion to date is that unless the equalization formula is carefully designed, provincial tax policy decisions are likely to be distorted. In the context of decentralized governance, it is essential to consider both transfer policy and tax assignment together if either is to achieve its intended objectives. $^{140}$

\section{Conclusion}

Canada's intergovernmental fiscal arrangements have been successful in maintaining a reasonably even provision of public services throughout a diverse country in which the major "people" services (education, health and social assistance) are constitutionally in the hands of provincial governments with very different financial capacities. Moreover, this has been accomplished without impinging unduly upon provincial freedom to act autonomously in most regards.

On the other hand, some have argued that although Canada's equalization transfers may have succeeded in maintaining relative high living standards in poorer regions, it may be that they

\footnotetext{
${ }^{138}$ See Michael Smart Michael Smart, 2007. "Raising taxes through equalization" (2007) 40(4) Canadian Journal of Economics 1188-1212. Even if federal transfer policies have led to higher provincial taxes in some areas, the outcome need not always be welfare-decreasing for the nation as a whole. Two recent contributions consider an environment in which competition among local governments for a mobile tax base tends to drive local tax rates lower than a unitary decision-maker would choose-the 'race to the bottom' scenario. See Sam Bucovetsky \& Michael Smart, "The Efficiency Consequences of Local Revenue Equalization: Tax Competition and Tax Distortions" (2006) 8(1) Journal of Public Economic Theory 119-144; and Marco Koethenbuerger, "Tax competition and fiscal equalization" (2002) 9 International Tax and Public Finance 391-408. The general finding is that a tax cut by a single region causes an inflow of the tax base to the region, which mitigates the revenue loss of the tax cut. However, this gain comes at the expense of government revenues in other regions, so the final outcome is an inefficient supply of public goods to the nation. In these circumstances, a capacity equalization grant by changing the fiscal consequences of a tax cut may limit such harmful tax competition. The reason is that the increase in the local tax base caused by a tax cut also reduces the deviating government's entitlement under the grant formula. This offsets the impact of the tax cut on own-source revenue, and so tends to increase equilibrium tax rates of all regions.

${ }^{139}$ See Brennan, G. and J. Buchanan, The Power to Tax (Cambridge University Press, 1980).

${ }^{140}$ The general tax assignment issue is beyond the scope of the present paper: for a brief treatment, see Richard $\mathrm{M}$. Bird, "Tax Assignment Revisited," in J.G. Head and R. Krever, eds., Tax Reform in the 21st Century (Kluwer Law International, 2009).
} 
have perpetuated rather than reduced regional economic inequality. ${ }^{141}$ Similarly, Canada's convoluted 'tax base sharing' arrangements may have preserved 'too much' provincial autonomy from the perspective of national economic growth. If solving one problem has exacerbated another, how one evaluates the situation depends in part upon the relative weight to be attached to each of these goals - and since such weights can realistically only be assessed through the political process, judgment is ultimately a matter not of economics or law but of political economy.

Even within this broader framework, however, assessment of the performance of Canada's intergovernmental system in reconciling provincial and national interests yields mixed results. Viewed from one perspective, the evolution of Canadian intergovernmental fiscal arrangements over the last half of the $20^{\text {th }}$ century offers a masterly demonstration of what has been called "federal-provincial diplomacy" at its best-and its worst. ${ }^{142}$ The "best" is that, as discussed with respect to income and sales tax sharing arrangements in 4.1 and 4.2 above, it worked. The country has stayed together, grown respectably, and in general treated most citizens fairly well and surprisingly uniformly, especially given the dominance of the provinces as providers of public services. The "worst" as illustrated to some extent by the discussion of natural resources in section 4.3 is that the process has been an unruly and noisy one that has consumed enormous political energies and may even have reduced Canada's ability as a state to cope effectively with the changing world.

One important aspect of the process of federal-provincial negotiation and compromise that has dominated taxation and fiscal federalism in Canada has been asymmetry in some federalprovincial arrangements, in particular to allow Québec to satisfy its expressed need for more autonomous policy. To some extent, there may also at times have been occasional fiscal benefits from this process of letting more than just the federal flower bloom.

It is clear that Québec has been a net fiscal gainer from the intergovernmental tax and fiscal arrangements we have discussed. ${ }^{143}$ Is this a problem? The answer may be 'no,' for at least three reasons. First, fiscal gains may offset current (or historical) federal policies that have led to real, or at least perceived, regional losses. Québec with its motto of "Je me souviens" may excel in this respect but it is by no means alone in Canada in viewing current intergovernmental finance in the context of its view of history, as noted earlier in the case of natural resource policy in Alberta. We might also have mentioned the long-standing belief of many in the Maritime provinces that the industrial heartland of central Canada (Ontario and Québec) was, so to speak, built at their expense by forcing them to buy high-priced Ontario goods after Confederation (in 1867) rather than buying from their traditional and cheaper suppliers in the

\footnotetext{
${ }^{141}$ See, for example, Thomas J. Courchene, "Avenues of Adjustment: The Transfer System and Regional Disparities" in M. Walker, Canadian Confederation at the Crossroads: The Search for a Federal-Provincial Balance (Vancouver: Fraser Institute, 1978).

142 The phrase in quotes is the title of a well-known book; see Richard Simeon, Federal-Provincial Diplomacy: The Making of Recent Policy in Canada (Toronto: University of Toronto Press, 1972).

${ }^{143}$ As suggested by the statistical evidence discussed in Francois Vaillancourt, "The Economics of Constitutional Options for Québec and Canada" 6(2) Canadian Business Economics 3-14.
} 
northeastern United States. Provinces, like people, usually have no difficulty in justifying their favourable treatment, and indeed, sometimes, such arguments may resonate even outside the region in question.

A second reason that Québec's fiscal gains need not be a problem is that differential treatment may be required to achieve uniform results. Canada's equalization system is based on precisely this argument since its design ensures that provinces incapable of financing from their own resources services at a certain level receives sufficient funds to enable them to do so. ${ }^{144}$ One may argue about the virtues of this system, as we noted earlier, but Canadians overall do not.

A third and final reason to find Québec's situation acceptable is that to some extent differential fiscal (or other) treatment is at times required simply to, as it were, "buy off" regional discontent and hold the country together. There is neither anything unique nor anything wrong about this approach. Politicians have since time immemorial traded favours for support, and probably every federal state in the world has at one time or another cut deals with particularly disaffected regions in order to reconcile them to staying within the system. In any case, to the extent that such forces have been at play, it should come as no surprise if the regions with the most credible threat potential-primarily Québec, of course-have done best out of this process (if indeed they have).

One way the conflict between the need for asymmetry and the desire for equal treatment has been reconciled has been by reducing federal controls over all provincial actions. However, this policy may have pernicious ramifications, in effect reducing the ability of Canada "as a whole" to do anything very effectively. There has long been, for example, an articulate strand of Canadian opinion that thinks a much stronger and more direct federal role is both appropriate and needed in areas such as health, education, and welfare policy if all Canadian citizens are really to be treated as equally as, in the opinion of those holding such views, they should be. ${ }^{145}$

Nonetheless, Canada has managed, through much intergovernmental maneuvering over the last fifty years, both to hold the country together and to provide a relatively uniform package of public services to citizens. But how much longer can, in the words of Yeats, "the centre hold" before it breaks under the combined stress of strengthened provincial assertiveness-most importantly but not solely in Québec-and the evolution of a continental common market?

Can the fiscal juggling act of the last half-century be long continued? The impact of globalization on Canada's diverse regions suggests that further sub-constitutional 'muddling through' may not suffice. For example, to the extent that in the past the central government used its financial resources to, as it were, buy tranquility in restless regions, it is unlikely to be able to do so in

\footnotetext{
${ }^{144}$ Equalization as it works in Canada is of course a one-way street in that it does nothing to "level down" those who are above the specified level, but this does not affect the point made in the text.

${ }^{145}$ For examples, see E.M. Hall, Canada's National-Provincial Health Program for the 1980s (Ottawa, 1980) and A. Johnson, Giving Point and Purpose to the Federal Financing of Post-Secondary Education and Research in Canada (Ottawa, 1985).
} 
the future to anything like the same extent. ${ }^{146}$ The economy may continue to expand but the ability of governments at all levels to extract greater resources may more likely to diminish than to expand as a result. Moreover, to the extent expansion is driven by demand for Canada's resources the regional effects will be very diverse and will put more strain on the federation. Since resources are controlled by the provinces, the effect will be to strengthen some provincial treasuries, thus increasing regional diversity. The question is whether the "winning" provinces will be willing to provide increased support to enable 'losers' elsewhere to keep up. ${ }^{147}$ The answer is not clear.

Québec remains to some extent a wild card in the Canadian deck. In economic terms, it may not be one of the big winners from globalization (or continental integration) but the process means that it also likely has less to gain from remaining part of Canada. As "Canada" becomes both a relatively less important economic factor in people's lives and the popular perception of its political reality becomes even vaguer in the Québec milieu, the likelihood of a popular vote for, as it were, permanently opting out seems at least as likely to increase as to diminish. What would happen if Québec did separate is completely unpredictable. It may be that, after some time, the whole system would shake down and life would go on much as before both for "Québécois" and those left in the ROC (Rest of Canada). Or it may be that years of acrimonious debate and much bad feeling on both sides may ensue, with either side (or both) ending up much worse off. All we can say here is that obviously no jiggling of intergovernmental fiscal arrangements can put Humpty-Dumpty together again if either Québec or the rest of Canada decides not to play the game any longer.

An additional complication is that, as evidenced by some recent discussion of the health system, the focus of discussion has shifted from the traditional federal-provincial (executive) forum in which major sub-constitutional decisions have in effect been made to an interprovincial forum. Alternatively, or in a complementary fashion, some governmental functions may come increasingly to be seen as "joint" responsibilities of both levels of government. The extent to which CRA, which already plays a decisive role in collecting provincial taxes, becomes more responsive to diverse provincial interests and provides a forum in which all those affected-provinces and federal government alike-can discuss and resolve technical (and ultimately political) issues about who gets what, when and in what form will be interesting to observe. Given Canada's somewhat checkered recent history of constitutional

\footnotetext{
${ }^{146}$ A similar argument is made by Richard M. Bird, M.W. Bucovetsky, and David Foot, The Growth of Public Employment in Canada (Montreal : Institute for Research in Public Policy, 1979). Since the country survived the next two decades in the face of increasing stress, Canadian politicians obviously proved to be more adept managers than was assumed in this analysis. Nonetheless, past success is not necessarily an augury of future success in the face of what may be troubling times for those who would solve problems by spending public money. 147 Incidentally, to the extent one rationale underlying the apparent generosity of the rich regions in supporting Canada's present redistributive system is to discourage people from migrating from poor regions, this rationale would seem to provide relatively less support for transfers to Québec since, as we have argued, francophone Canadians are less likely to migrate in any case.
} 
reform ${ }^{148}$ should this form of intergovernmental co-operation develop to any extent, it seems likely that it will continue, as in the past, to occur seriatim and largely out of public sight as governments at both levels attempt to cope with the pressures they will all be facing.

However, even in the relatively favourable circumstances envisaged in the immediately preceding paragraph-with everyone in an unusually co-operative mood - it seems most unlikely that the problems the Canadian federation may face in the next few decades can readily be resolved within the existing political structure. The virtually complete absence of any formal mechanism for provincial representation at the federal level in Canada, combined with the strong federal party system, executive dominance of the legislature, and the lack of any integration between federal and provincial parties, means that virtually every issue in Canadian politics sooner or later becomes a matter for federal-provincial conflict and confrontation. It seems unlikely that approaches to co-operative solutions like those just mentioned can easily emerge in a system in which the other side is almost invariably seen as the "enemy". How, if at all, this problem can be resolved is not at all clear, since the foxes who would almost surely lose power if it were resolved are currently in control of the relevant hen-houses.

${ }^{148}$ For example, as summarized in Richard M. Bird and Francois Vaillancourt, "Changing with the Times: Success, Failure and Inertia in Canadian Federal Arrangements, 1945-2002" in T. N. Srinivasan, Jessica Seddon Wallack, eds., Federalism and Economic Reform: International Perspectives (New York: Cambridge University Press, 2006 